
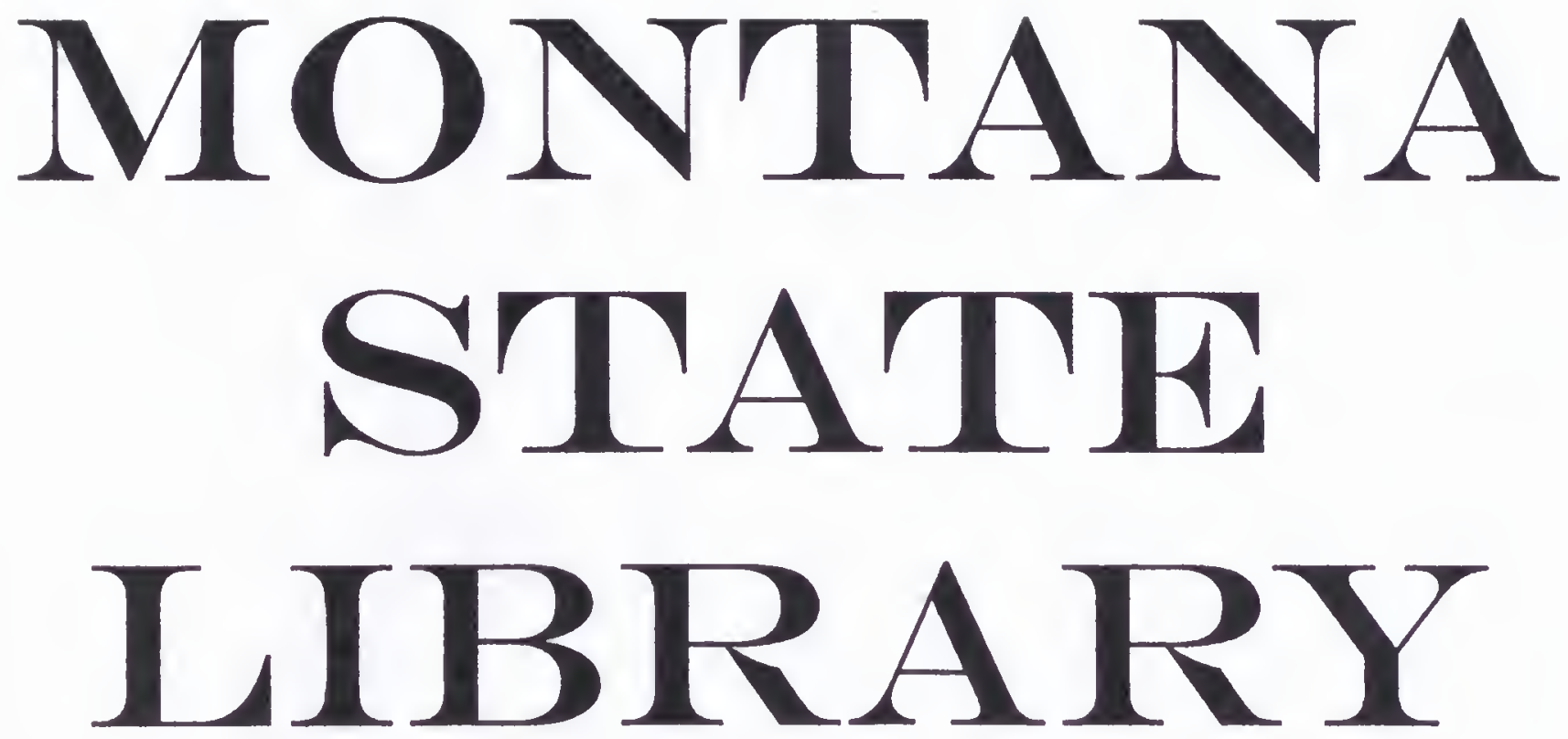

This "cover" page added by the Internet Archive for formatting purposes 



\section{TEE 1?:9993}

MONTANA STATE LIERARY

1515 E. 6th AVE.

HELENA, MONTANA 59520

UPDATE TO THE STATUS REVIEW

OF Howellia aquatilis

FIELD SURVEYS, MONITORING STUDIES, AND TRANSPLANT EXPERIMENTS

1990

Prepared for:

U.S.D.A. Forest Service Flathead National Forest 1935 Third Avenue East Kalispell, MT 59901

Prepared by:

Lisa A. Schassberger

Montana Natural Heritage Program

state Library Building

$1515 \mathrm{E}$. 6th Avenue

Helena, MT 59620

and

J. Stephen Shelly

U.S.D.A. Forest Service, Region 1 Range, Air, Watershed and Ecology P.O. Box 7669

Missoula, MT 59807

order No. 43-0385-0-0279

March 1991

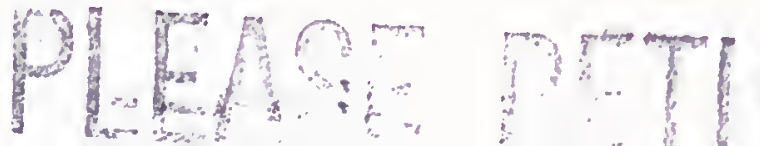




\section{This is an abridged report}

For the full report please contact:

The Montana Natural Heritage Program

1515 E Sixth Ave

Helena, Montana 59620

406-444-3009 
Page

ACKNOWLEDGEMENTS ....................... i

SUMMARY................................. ii

I. INTRODUCTION........................... 1

II.

REVIEW OF PRESENT STATUS...................

III.

UPDATE OF GEOGRAPHIC DISTRIBUTION.

IV. MONITORING STUDIES.

v.

TRANSPLANT EXPERIMENTS.

VI. STUDY RECOMMENDATIONS . 20

VII.

ELEMENT OCCURRENCE PRINT-OUTS AND MAPS: NEW SITES...

IX. MAPS OF PONDS SURVEYED WITHOUT SUCCESS............ 


\section{ACRNOWLEDGMENTS}

Tom wittinger and Nancy Warren, Flathead National Forest, and Angie Evenden, U.S. Forest Service Region 1, have been very supportive throughout these studies. Ron Mellem, Flathead National Forest, provided aerial photographs for use during field surveys. Peter Lesica provided valuable insights regarding transplant methods. Jim stimson put in a great deal of time on the climatological maps. Maria Mantas provided assistance with field surveys, and the monitoring studies. 


\section{SUMMARY}

Howellia aquatilis Gray (Campanulaceae) is currently included on the sensitive (Montana) and watch (Idaho) species lists in Region 1 of the U.S. Forest Service (U.S. Department of Agriculture 1988; Reel et al. 1989), and the sensitive list in Region 5 (Shelly and Moseley 1988). It was recently recognized (1990) as a Category 1 (candidate) species by the U.S. Fish and Wildilfe Service, and is being considered for listing under the Federal Endangered Species Act of 1973. Survey work for this species has been ongoing in Montana since 1987, resulting in a total of 59 occurrences, clustered into 9 pond groups. Two of the 59 populations were located in 1990. Thirty-eight populations (50\% of those known globally) occur wholly or partialiy on Flathead National Forest lands. Also, six ponds were surveyed which did not contain $\underline{H}$. aquatilis, bringing the total number of ponds surveyed in Montana to 428 . Results of population size estimates (1987, 1989, 1990) and data obtained from transects utilizing line-intercept $(1987,1989,1990)$ and frequency measures (1989, 1990) show that the population sizes of this annual species fluctuate from year to year. Population size fluctuations correlate well to climate factors of precipitation and temperature; these factors affect the drying time of ponds in fall when germination occurs. Seeds of $\underline{H}$. aquatilis do not germinate under water, thus it is hypothesized that in years when precipitation is above normal and temperatures are below normal (such as in 1988 and in 1989), ponds do not dry out or dry out late in the year. The result may be a reduction in population size the following year (as was observed in 1989 and 1990). The transplant experiments were partially successful. A small number of plants were established in two of the transplant ponds in 1990 (Pond A: 32 plants, and Pond B: 5 plants). Both ponds contained plants that were reproductive. Two other ponds ( $C$ and D) contained no plants; these ponds had water in them when the transplants were done in september, and probably did not dry out much more prior to freezing. This appears to confirm the fact that $\underline{H}$. aquatilis seeds do not germinate under water. While the transplants to ponds $A$ and $B$ could be considered a success in 1990, it remains to be seen whether or not these small $\mathrm{H}$. aquatilis populations are present next year or thereafter. Recommendations are made for continuing studies. 


\section{INTRODUCTION}

This report summarizes the results of monitoring studies and field surveys conducted from 1987-1990, to assess the status of Howellia aquatilis Gray (Campanulaceae). This species is designated as a sensitive plant by Region 1 of the U.S. Forest Service, and occurs on the Flathead National Forest. Previous reports summarize the status of research conducted prior to the 1990 field season (Shelly 1988, 1989; Shelly and Schassberger 1990).

The field work conducted in 1990 represents the second year of a three-year inventory and analysis project. The purpose of this project is to assemble adequate information on the distribution and status of the species, in order to prepare a U. S. Forest Service species management guide. The 1990 goals were:

1.) continue field surveys of potential habitat for $\underline{H}$. aquatilis on the Flathead National Forest and adjacent lands.

2.) resurvey 26 populations, emphasizing those found on Flathead National Forest lands, to obtain ongoing estimates of population size, condition, persistence, and response to management practices.

3.) monitor transplant experiments (soil plugs from ponds with high densities of $\underline{H}$. aquatilis were placed in unoccupied potential habitats at four locations in september of 1989): read transects to determine success of transplants.

5.) continue quantitative monitoring studies established at five locations in 1988; includes line intercept and frequency measurements.

Field studies were conducted by the authors (Montana Natural Heritage Program/U.S. Forest Service). Surveys and monitoring studies were conducted 10-13 and 16-19 July 1990.

\section{REVIEW OF PRESENT STATUS}

Howellia aquatilis is currently included on the sensitive (Montana) and watch (Idaho) species lists in Region 1 of the U.S. Forest Service (U.S. Department of Agriculture 1988; Reel et al. 1989), and the sensitive list in Region 5 (Shelly and Moseley 1988). It was recently recognized as a Category 1 (candidate) species by the U.S. Fish and Wildlife service, and is being considered for 1 isting under the Federal Endangered species Act of 1973. A Category 1 species is one for which there is substantial biological information on file to support the appropriateness of proposing to list the species as endangered or threatened (U.S. Department of Interior 1990). It was 
recommended by shelly and Moseley (1988) that this species be moved from Category 2 to Category 1 for several reasons: (1) the species has been extirpated from a large portion of its previously known global range, (2) it has a narrow ecological amplitude, (3) it lacks detectable inter- and intrapopulation genetic variation, and (4) habitat alteration continues in a major portion of its extant range.

\section{UPDATE OF GEOGRAPHIC DISTRIBUTION}

Upon conclusion of the 1990 field season, $\underline{H}$. aquatilis was documented from a total of 76 extant populations worldwide: 1 in Idaho, 59 in Montana, and 16 in Washington. All known Montana populations are located in the Swan River drainage (Lake and Missoula counties). Within this drainage, a total of 428 wetlands have been surveyed; $\underline{H}$. aquatilis has been found in 59 (13.8\%) of them. The Montana populations constitute $77.6 \%$ of those known globally for the species. Thirty-eight populations ( $50 \%$ of those known globally) occur wholly or partially on Flathead National Forest lands. The land ownership status of the Montana populations is summarized in Table $1, \mathrm{p} .3$.

Two new populations were discovered in previously unsurveyed ponds (occurrence numbers 058 (Salmon Prairie), and 059 (Lost Creek-Cilly creek Ponds)). Six other previously unsurveyed ponds were also examined, but did not contain $\underline{H}$. aquatilis. Element occurrence print-outs and location maps for the two new populations are included in section VII, pp. 21-25. The locations of the ponds that were surveyed, but do not support $\underline{H}$. aquatilis, are indicated on maps in section IX, pp. 53-55.

Although H. aquatilis has not been found to occur outside of the Swan Valley. in Montana, on the recommendation of Maria Mantas (Flathead National Forest), ponds which look suitable in the Lake Five area near West Glacier, Montana, should be surveyed in 1991.

\section{MONITORING STUDIES}

Details regarding population size and condition for the two newly discovered occurrences are summarized in Table 2, p. 4 .

During 1990, 26 previously documented populations were resurveyed, and estimates of population size and percent of each pond occupied by $\underline{H}$. aquatilis were made. Updated occurrence records for these ponds are provided in section VIII., pp. 26-52. Quantitative monitoring studies of five populations (008, 009, 013, 020, and 027) were continued. The locations of the resurveyed ponds and the long-term monitoring ponds are in an earlier status review (Shelly 1988). The methods for the quantitative monitoring studies are described in a report by Shelly (1989). 
Table 1. Summary of land ownership for Montana populations of Howellia aquatilis (1990).

\begin{tabular}{lllll}
\hline Canty & Site name & $\begin{array}{l}\text { Number of } \\
\text { populations on } \\
\text { Flathead N.F. } \\
\text { lands }\end{array}$ & $\begin{array}{l}\text { Number of } \\
\text { populations on } \\
\text { Flathead N.F. and } \\
\text { private lands }\end{array}$ & $\begin{array}{l}\text { Number of } \\
\text { populations on } \\
\text { private lands }\end{array}$ \\
\hline Lake & $\begin{array}{l}\text { Lost Creek } \\
\text { Cilly Creek }\end{array}$ & 12 & 0 & 0 \\
Lake & Dog Creek & 2 & 0 & 0 \\
Lake & Swan River West & 1 & 0 & 0 \\
Lake & Salmon Prairie & 0 & 1 & 1 \\
Lake & Swan River Oxbow & 0 & 1 & 0 \\
Missoula & Condon Creek & 9 & 0 & 4 \\
Missoula & Elk Creek & 1 & 1 & 1 \\
Missoula & Kraft Creek & 0 & 0 & 15 \\
Missoula & Lindbergh Lake & 9 & 1 & 21 \\
\hline TorAl & & 34 & 6 & 0 \\
\hline
\end{tabular}


Table 2. Population size and condition for Howellia aquatilis occurrences newly documented in 1989.

Occurrence number: 058

Site name: SALMON PRAIRIE

Acreage: 1

Population size and condition: 11-50 PLANTS COUNTED IN 1990; POND CURRENTLY SURROUNDED BY DENSE, UNDISTURBED TIMBER STANDS.

Occurrence number: 059

site name: LOST CREEK-CILLY CREEK PONDS

Acreage: 1 Population size and condition: CA. 150 PLANTS COUNTED; ALL INDIVIDUALS OCCUR NEAR MIDDLE OF POND NEXT TO
LOG; SHALLOW POND ( 2 FT. DEEP IN MOST PLACES) WITH FEW OPEN AREAS FOR PLANTS TO BECOME ESTABLISHED; SURROUNOING FOREST CURRENTLY INTACT. 
RESULTS: The results of the population size surveys are presented in Table 3, p. 7. As stated in a previous report (Shelly and Schassberger 1990), these figures are to be strictly regarded as estimates. Nonetheless, they do indicate that populations remained fairly stable in size from 1987 to 1989 ; however, between 1989 and 1990, 20 populations were reduced in size by at least 50 percent, and 14 were reduced by more than 75 percent of the previous years' estimates. Anomalies over the period from 1987-1990 include the reduction in population size of H. aquatilis in occurrence 012 between 1987 an 1989 (while most other ponds remained the same or showed an increase in population size), and a slight increase in size of this same population in 1990 (while nearly all other ponds showed a reduction in population size). Population (026) showed an increase in population size between 1987 and 1989 (similar to most populations), but the population size again increased between 1989 and 1990 (contrary to all but population 012).

Also included in Table 3 are 1990 estimates of the percentage of each pond that is occupied by $\underline{H}$. aquatilis. These estimates correlate well with the population size estimates (smaller populations generaliy occupy the smallest percentage of suitable habitat).

The results from the line-transect studies for three years are presented in Table 4, pp. 8-9. The four ponds for which water depth measurements were taken in both 1988 and 1989 were all deeper during the second year, with pond numbers 020 and 027 significantly deeper in 1989. In 1990, pond number 008 was only slightly less deep than in 1989, pond 013 remained the same (013), while the rest were slightly more deep.

As reflected in the population size estimates for the five ponds, line-transect data indicate that the percent cover of $\underline{H}$. aquatilis was significantly lower in 1990 than in 1988 or 1989. Large population fluctuations reflect this species' annual habit, and the apparent influence of fluctuating water levels on yearly abundance.

Frequency measures for the five line-transect ponds indicated a less extreme drop in estimated population sizes between 1989 and 1990 than either the population estimate or line-transect methods. Results are presented in Table 4, p. 8 .

DIScussIoN: Populations were observed to be greatly reduced in 1990, as shown by the results of line-transect, frequency and population size estimate studies. As stated in Lesica (1990), the possible reasons for fluctuating sizes of $\underline{H}$. aquatilis populations include date of pond drying each year. The observed decline in population size in nearly all the surveyed ponds in 1990 may reflect a suboptimal drying regime in 1989. Climate data, including precipitation and temperature data from 
January 1986-September 1990, for stations at Bigfork (Figure 1 and 2), and Seeley Lake (Figure 3 and 4), Montana, are provided on pp. 10-11 and 12-13, respectively (U.S. Department of Commerce 1982). Data indicate that total precipitation at Bigfork and Seeley Lake was below normal in 1988, but above normal in 1989 (Figure 1 and 3 , pp. 10 and 12 , respectively). The average yearly temperature was also below normal for both stations in 1989 (Figure 2 and 4, pp. 11 and 13, respectively), although not from January through August of 1990. More specifically, for August and September of 1989 (when germination might begin) temperatures were below normal for both stations. Finally, for the five monitoring ponds from 1988 to 1989 (Table 4, p. 8) pond depths were $10,30,40$, and 55 percent deeper (ponds 008, 009, 013, 020, and 027 respectively) in 1989. In 1990, monitoring ponds were slightly deeper. Although this latter measurement is approximate (depth was measured with a meter stick each time and the stick may have been pushed deeper into the pond substrate from one year to the next), it still reflects a significant increase in water depth between 1988 and 1989. In combination, these factors could have resulted in less than optimal germination conditions for $\underline{H}$. aquatilis in the fall of 1989 , the outcome of which was the observed decrease in population size in 1990. Every pond is probably different with respect to drying regime, and therefore trend in population size. This may explain the anomalous results reported for ponds 12 and 26 over the past three years. If seed germination is enhanced when ponds are dry, then for most of the ponds, suboptimal drying regimes were present between 1989 and 1990.

climate data are currently only available through september of 1990; however, for both the Bigfork and seeley Lake stations, precipitation appears to have been below normal and temperatures above normal. Low $\underline{H}$. aquatilis population counts might persist through 1991, since the latter half of 1990 was mostly above normal with respect to precipitation (Figure 1 and 3 ), and the depth measurements were similar to 1989 levels. However, if a warmer and dryer trend occurs through summer of 1991, population counts in 1992 would be predicted to be higher for most ponds.

Also of interest in the 1990 surveys was the number of ponds that were deep yellow-red in color, and had what appeared to be an oily slick on the surface of the water. It is postulated that if water levels remained high through the fall, more leaf material would remain in the water which would not decompose, but would instead leach into the water. The oil slick may also be an end product of leaching. In any case, a reduction in incoming light due to discoloration might also limit survival of $\underline{H}$. aquatilis seedlings, resulting in smaller populations as observed in 1990. Heavy algal growth present may be the result of higher water temperatures. Algal growth could also limit establishment of $\mathrm{H}$. aquatilis seedlings. 
Table 3. Population size estimates (number of individuals), and percentage of pond occupied, for 26 Howellia aquatilis occurrences, Swan River Valley, Montana (1987, 1989, 1990).

\begin{tabular}{|c|c|c|c|c|c|}
\hline $\begin{array}{l}\text { OCARRENCE } \\
\text { MUABER }\end{array}$ & 1987 & \multicolumn{2}{|c|}{$\begin{array}{l}\text { EST. Z OF POND } \\
\text { OCOPIED (1989) }\end{array}$} & \multicolumn{2}{|c|}{$\begin{array}{l}\text { EST. I OF POWD } \\
\text { OCCIPIED (1990) }\end{array}$} \\
\hline $\begin{array}{l}001 * \\
006 \\
007 \\
008 \\
009 * \\
012 * \\
013^{*} \\
014^{*} \\
016 \\
017\end{array}$ & $\begin{array}{l}75-100+ \\
1000-2000 \\
3000-4000 \\
2000-3000 \\
500-600 \\
400-500 \\
1000-1500 \\
300-400 \\
400+ \\
10-12\end{array}$ & $\begin{array}{l}300-400 \\
1000-2000 \\
1000-2000 \\
1000-1500 \\
500-1000 \\
16 \\
500-1000 \\
500+ \\
1000-1500 \\
10-20\end{array}$ & $\begin{array}{l}60 \\
50 \\
95 \\
50 \\
30 \\
<5 \\
50 \\
50 \\
85 \\
<5\end{array}$ & $\begin{array}{l}27 \\
500-1000 \\
500-600 \\
40+ \\
220+ \\
35 \\
33 \\
150-250 \\
300-500 \\
0\end{array}$ & $\begin{array}{l}<5 \\
20 \\
30 \\
10 \\
20 \\
<5 \\
5 \\
30 \\
30,(c \text { lumped }) \\
\left(\#^{1}\right)\end{array}$ \\
\hline $\begin{array}{l}020 \\
022 \\
023 \\
025\end{array}$ & $\begin{array}{l}1000 \\
200 \\
3 \\
25\end{array}$ & $\begin{array}{l}1000-1500 \\
500 \cdot 1000 \\
400-500 \\
100-125\end{array}$ & $\begin{array}{l}60 \\
70 \\
55 \\
<5\end{array}$ & $\begin{array}{l}190+ \\
60-100 \\
20 \\
0\end{array}$ & $\begin{array}{l}20 \\
25 \\
<5 \\
\left(n^{2}\right)\end{array}$ \\
\hline $\begin{array}{l}026 \\
027^{*} \\
029 \\
030^{\circ}\end{array}$ & $\begin{array}{l}200 \cdot 300 \\
300 \\
200 \cdot 300 \\
1000\end{array}$ & $\begin{array}{l}500 \cdot 1000 \\
300 \cdot 400 \\
500 \cdot 1000 \\
1000\end{array}$ & $\begin{array}{l}70 \\
40 \\
30 \\
55\end{array}$ & $\begin{array}{l}1000 \cdot 2000 \\
200+ \\
100 \cdot 200 \\
0\end{array}$ & $\begin{array}{l}70 \\
30 \\
10 \\
\left(n^{3}\right)\end{array}$ \\
\hline $\begin{array}{l}032 \\
035\end{array}$ & $\begin{array}{l}109.9000(1983) \\
51.9000(1983)\end{array}$ & $\begin{array}{l}750 \cdot 1000 \\
500 \cdot 750\end{array}$ & $\begin{array}{l}40 \\
40\end{array}$ & $\begin{array}{l}3 \cdot 10 \\
0\end{array}$ & ${ }^{5}\left(n^{4}\right)$ \\
\hline 046 & $275 \cdot 400$ & $90 \cdot 120$ & 60 & 0 & $\left(n^{4}\right)$ \\
\hline 045 & 300 & $300-400$ & 20 & 10 & c5 $\left(n^{5}\right)$ \\
\hline $\begin{array}{l}046^{\circ} \\
047^{*} \\
048^{*}\end{array}$ & $\begin{array}{l}50 \\
200 \\
250\end{array}$ & $\begin{array}{l}30 \cdot 50 \\
200 \cdot 300 \\
200\end{array}$ & $\begin{array}{l}<5 \\
20 \\
10\end{array}$ & $\begin{array}{l}3 \\
150 \\
0\end{array}$ & $\begin{array}{l}<5 \\
156 \\
\left(n^{6}\right)\end{array}$ \\
\hline 049 & $1500-2000$ & 2000 & 65 & $200-300$ & $15\left(*^{7}\right)$ \\
\hline
\end{tabular}

* Ponds whose margins or imediate surroundings have been physically impacted by timber harvesting.

Observations at selected sites $(1990)$.

\#- High. cover of carex vesicaria.

$\star^{2}$ - High cover of Nuphar variegatum and Carex vesicaria.

$\sharp^{3}$ - No apparent cause for lack of plants.

$\#^{4}$ - Oily scum on surface, water deep reddish-yellow to brown, possible dumping from road or decaying leaves.

$\sharp^{5}$ - Heary algal bloom.

$\#^{6}$ - Dead sedges and cat-tails, water level appears high.

$\#^{7}$ - High cover of Lema minor. 
Table 4. Monitoring transect data, Howellia aquatilis and major associated species, Swan Valley, Montana, 1988-90. Cover data expressed as percentage of transect length occupied by the "canopy" of each species, as measured along lineintercept transects.

Occurrence number

\begin{tabular}{|c|c|c|c|c|c|}
\hline & $\underline{008}$ & $\underline{009}$ & $\underline{013}$ & $\underline{020}$ & 027 \\
\hline $\begin{aligned} \text { Date read 1988: } & \\
& 1989: \\
& 1990:\end{aligned}$ & $\begin{array}{l}21 \mathrm{JUL} \\
12 \mathrm{JUL} \\
18 \mathrm{JUL}\end{array}$ & $\begin{array}{l}21 \mathrm{JUL} \\
12 \mathrm{JUL} \\
19 \mathrm{JUL}\end{array}$ & $\begin{array}{ll}21 & \mathrm{JUL} \\
11 \mathrm{JUL} \\
19 \mathrm{JUL}\end{array}$ & $\begin{array}{l}22 \mathrm{JUL} \\
14 \mathrm{JUL} \\
18 \mathrm{JUL}\end{array}$ & $\begin{array}{l}22 \mathrm{JUL} \\
13 \mathrm{JUL} \\
17 \mathrm{JUL}\end{array}$ \\
\hline $\begin{array}{l}\text { Transect } \\
\text { Iength }((B)\end{array}$ & 48.95 & 50.0 & 66.0 & 62.9 & 50.0 \\
\hline \multicolumn{6}{|l|}{ Water depth (dx) } \\
\hline Tape point $(m)$ : & $\begin{array}{l}20.0 \\
40.0\end{array}$ & $\begin{array}{l}20.0 \\
40.0\end{array}$ & $\begin{array}{l}15.0 \\
30.0\end{array}$ & $\begin{array}{l}10.0 \\
23.0\end{array}$ & $\begin{array}{l}15.0 \\
30.0\end{array}$ \\
\hline 1988 & $\begin{array}{l}\text { not } \\
\text { measured }\end{array}$ & $\begin{array}{l}3.1 \\
3.2\end{array}$ & $\begin{array}{l}1.7 \\
1.8\end{array}$ & $\begin{array}{l}2.72 \\
2.64\end{array}$ & $\begin{array}{l}1.96 \\
1.50\end{array}$ \\
\hline 1989 & $\begin{array}{l}3.4 \\
4.95\end{array}$ & $\begin{array}{l}3.45 \\
3.55\end{array}$ & $\begin{array}{l}2.4 \\
2.2\end{array}$ & $\begin{array}{l}4.65 \\
6.35\end{array}$ & $\begin{array}{l}4.5 \\
4.0\end{array}$ \\
\hline 1990 & $\begin{array}{l}3.1 \\
4.06\end{array}$ & $\begin{array}{l}3.6 \\
3.81\end{array}$ & $\begin{array}{l}2.4 \\
2.1\end{array}$ & $\begin{array}{l}4.8 \\
4.75\end{array}$ & $\begin{array}{l}4.7 \\
4.5\end{array}$ \\
\hline Estimented $X$ cover: & $\begin{array}{l}1988 \\
1989 \\
1990\end{array}$ & & & & \\
\hline Howell ia aquatilis & $\begin{array}{l}8.21 \\
27.40 \\
2.01\end{array}$ & $\begin{array}{l}7.06 \\
7.24 \\
2.95\end{array}$ & $\begin{array}{l}6.46 \\
4.87 \\
0.83\end{array}$ & $\begin{array}{l}26.29 \\
59.21 \\
6.13\end{array}$ & $\begin{array}{l}1.80 \\
5.86 \\
3.28\end{array}$ \\
\hline $\begin{array}{r}\text { * frequency 1989: } \\
\text { 1990: }\end{array}$ & $\begin{array}{l}56 \\
25\end{array}$ & $\begin{array}{l}36 \\
18\end{array}$ & $\begin{array}{l}69 \\
16\end{array}$ & $\begin{array}{l}95 \\
19\end{array}$ & $\begin{array}{r}40 \\
8\end{array}$ \\
\hline$\frac{\text { Alopecurus }}{\text { dequal is }}$ & $\begin{array}{c}- \\
2.85\end{array}$ & : & - & 8.74 & : \\
\hline Carex atherodes & : & : & : & 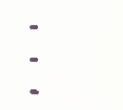 & $\begin{array}{l}9.40 \\
34.0 \\
1.90\end{array}$ \\
\hline Carex rostrata & $\begin{array}{l}19.10 \\
32.93 \\
24.25\end{array}$ & : & $\begin{array}{l}19.37 \\
20.37 \\
26.27\end{array}$ & $\begin{array}{l}9.88 \\
9.98 \\
15.52\end{array}$ & $\begin{array}{l}14.96 \\
14.2 \\
32.0\end{array}$ \\
\hline Carex vesicaria & $\begin{array}{l}6.41 \\
6.50 \\
7.66\end{array}$ & $\begin{array}{l}1.94 \\
2.00 \\
8.50\end{array}$ & $\begin{array}{l}55.72 \\
52.74 \\
57.80\end{array}$ & $\begin{array}{l}10.96 \\
16.81 \\
12.80\end{array}$ & $\begin{array}{l}1.66 \\
22.64 \\
4.20\end{array}$ \\
\hline
\end{tabular}


Table 4 (cont.)

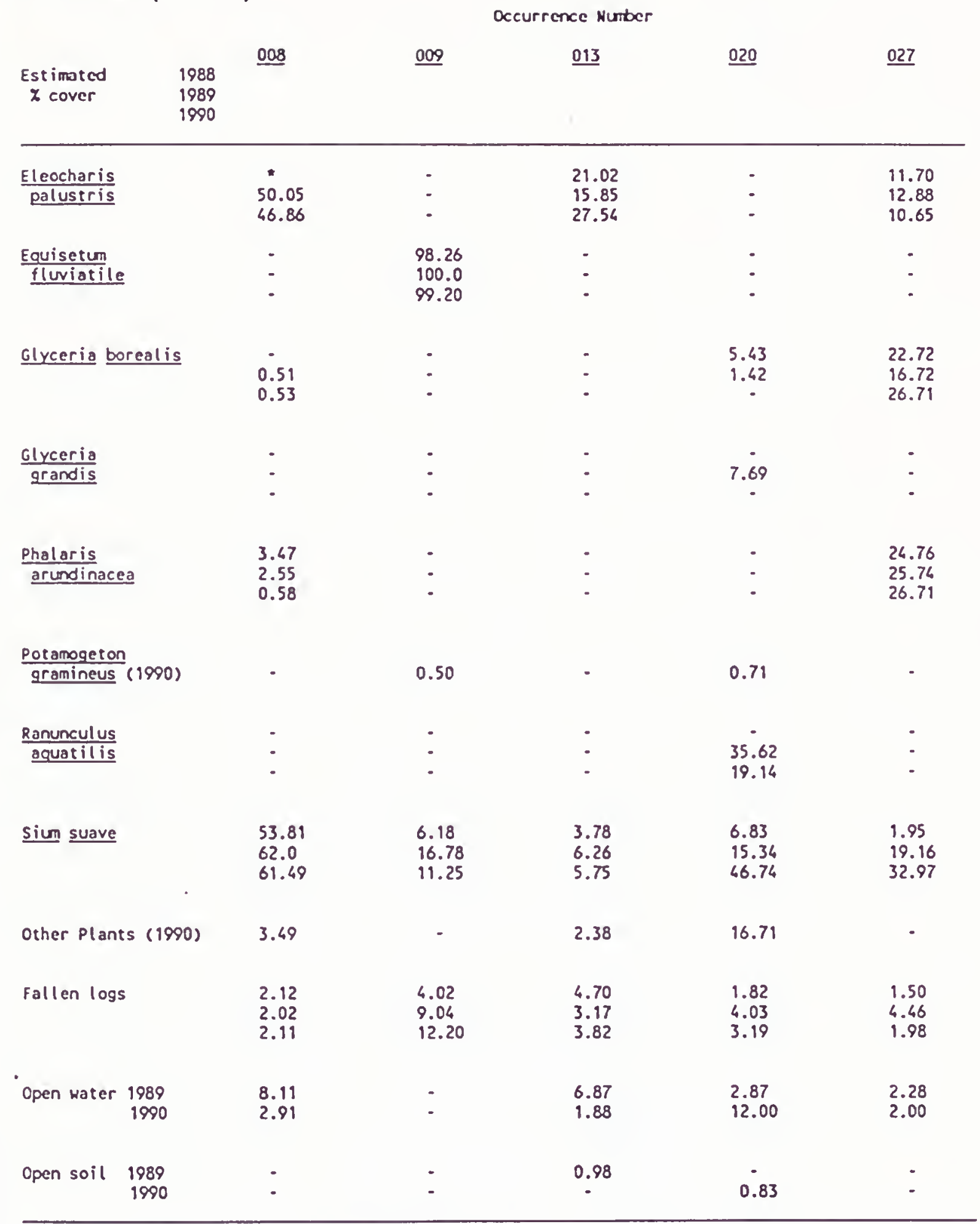

- Eleocharis palustris was scattered throughout the pond (1988). 


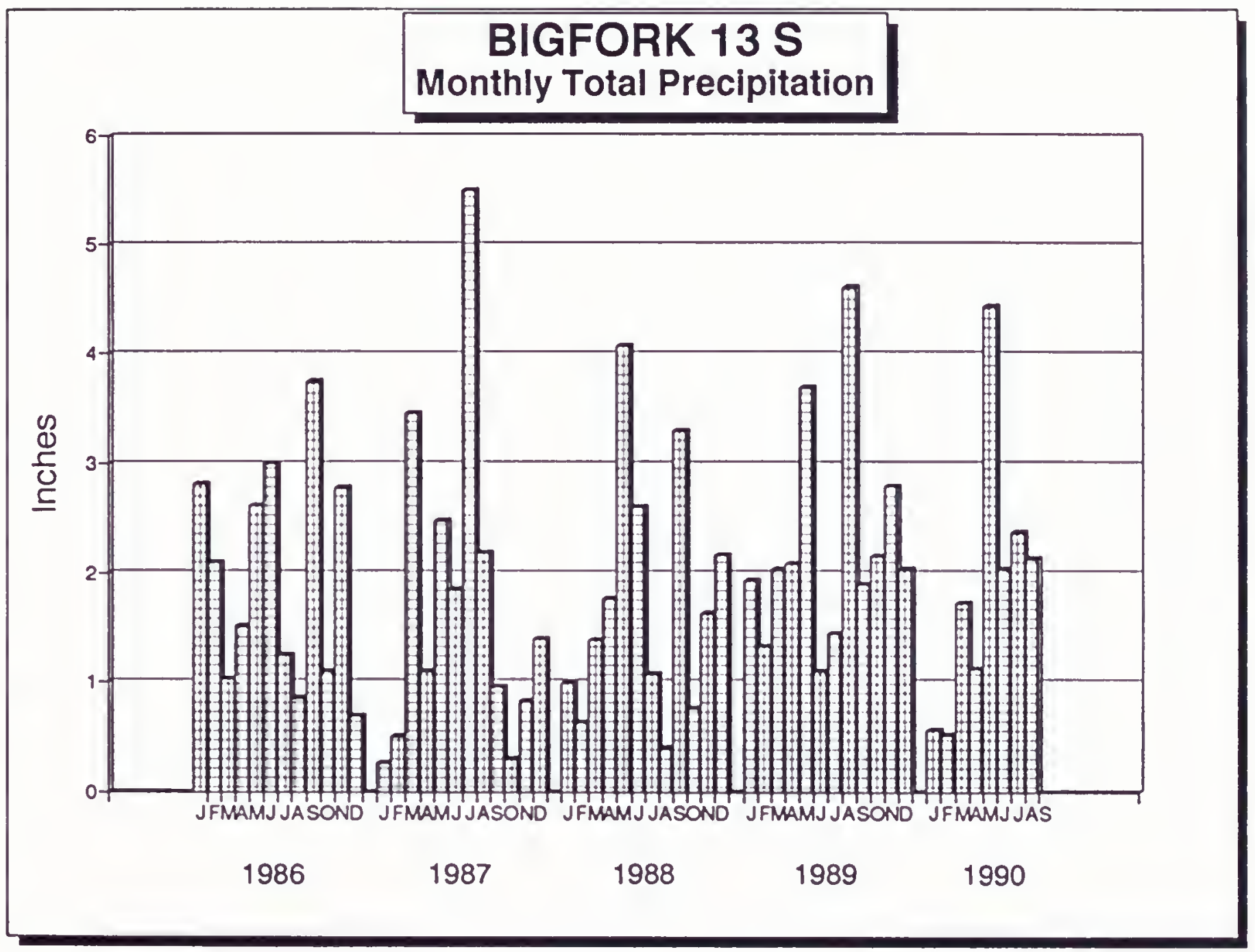

\section{BIGFORR 238 PRECIPITATION DATA "}

$\begin{array}{llllllllllllll}\text { YEAR } & \text { JAN } & \text { FEB } & \text { MAR } & \text { APR } & \underline{\text { MAY }} & \underline{\text { JUN }} & \underline{\text { JUL }} & \underline{\text { AUG }} & \underline{\text { SEP }} & \underline{\text { OCT }} & \underline{\text { NOV }} & \underline{\text { DEC }} & \underline{\text { TOT }} \\ 1986 & 2.81 & 2.09 & 1.03 & 1.51 & 2.61 & 3.00 & 1.24 & 0.85 & 3.75 & 1.10 & 2.77 & 0.69 & 23.45 \\ & 0.61 & 0.72 & (0.21) & 0.05 & 0.23 & 0.02 & (0.08) & (0.98) & 1.98 & (0.5) & 0.99 & (1.46) & 1.37 \\ 1987 & 0.26 & 0.50 & 3.46 & 1.10 & 2.47 & 1.85 & 5.50 & 2.18 & 0.96 & 0.30 & 0.83 & 1.40 & 20.81 \\ & (1.97) & (0.87) & 2.22 & 0.36 & 0.09 & (1.13) & (4.18) & - & (0.81) & (1.30) & (0.95) & (0.75) & - \\ 1988 & 0.99 & 0.63 & 1.38 & 1.77 & 4.07 & 2.60 & 1.07 & 0.40 & 3.29 & 0.76 & 1.63 & 2.16 & 20.75 \\ & (1.21) & (0.74) & 0.14 & 0.31 & 1.69 & (0.38) & (0.25) & (1.43) & (1.52) & (0.84) & (0.15) & 0.01 & (1.33) \\ 1989 & 1.93 & 1.33 & 2.03 & 2.08 & 3.69 & 1.09 & 1.44 & 4.60 & 1.89 & 2.15 & 2.78 & 2.03 & 27.04 \\ & (0.27) & (0.04) & 0.79 & 0.62 & 1.31 & (1.89) & 0.12 & 2.77 & 0.12 & 0.55 & 1.00 & (0.12) & 4.96 \\ 1990 & 0.56 & 0.51 & 1.72 & 1.12 & 4.43 & 2.03 & 2.37 & 2.13 & 0.00 & -. & & & \\ & (1.64) & - & -. & (3.4) & 2.05 & (0.95) & 1.05 & 0.30 & (1.77) & & & -. & \cdots\end{array}$

* FIRST LINE CONTANNS TOTALS, SECOND LINE CONTAINS DEPARTURES FROM NORMAL (1951.1980) - INDICATES MISSING DATA FOR THAT MONTH

NUMBERS IN PARENTHESES () ARE NEGATIVE VALUES 
FIGURE 2

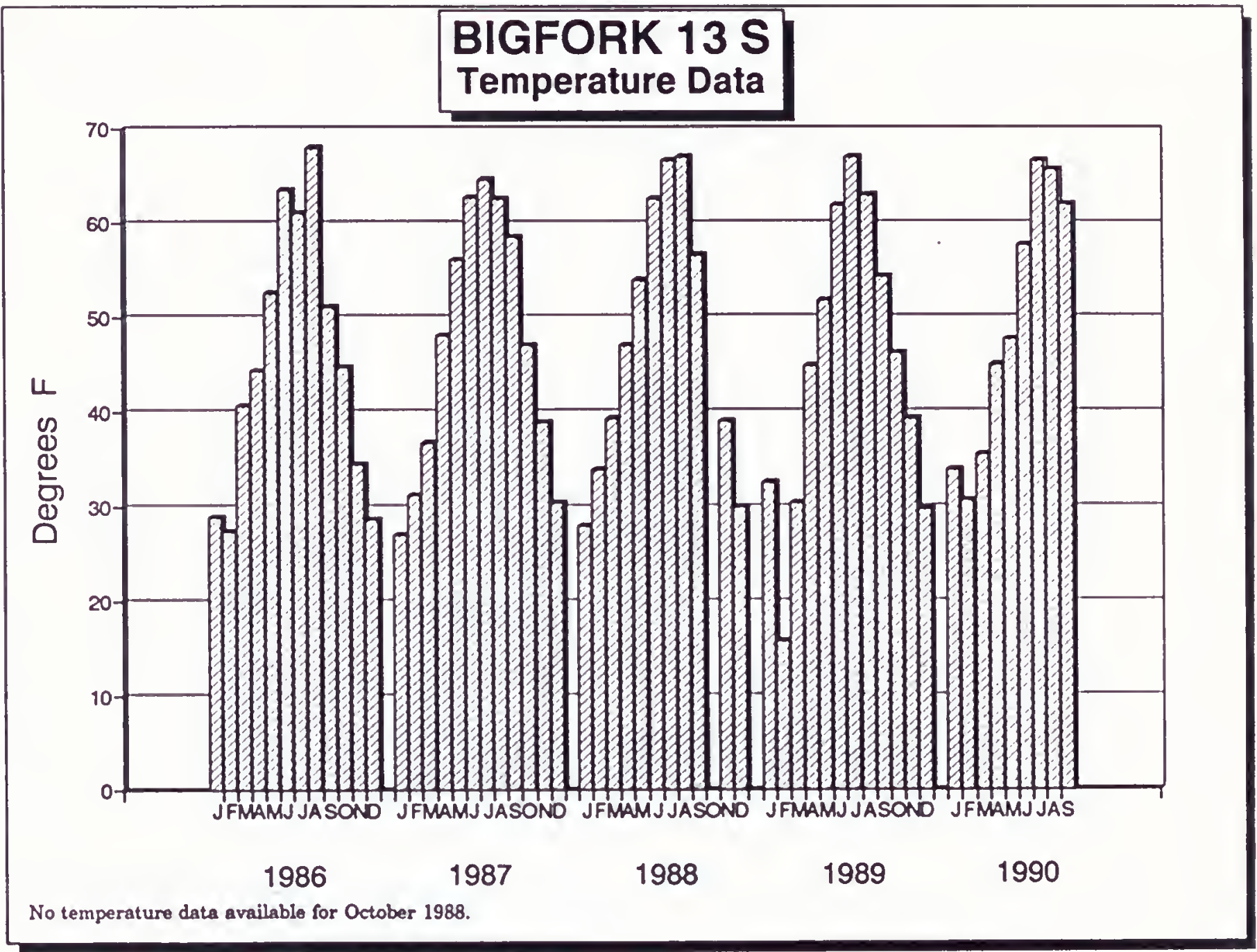

\section{BIGFORK 138 TEMPERATURE DATA *}

YEAR JAN FEB MAR APR MAY JUN JUL AUG SEP OCT $\underline{\text { NOV DEC TOT }}$

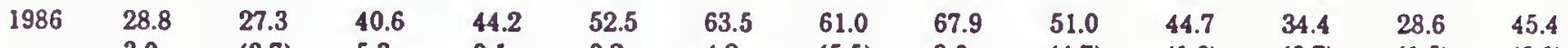

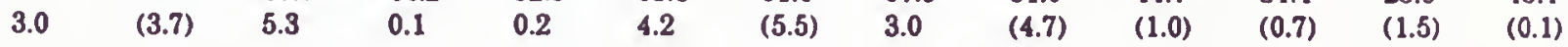

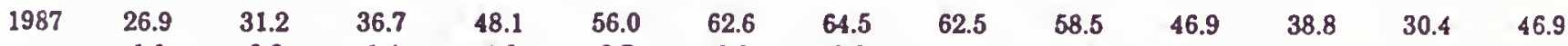
$\begin{array}{lllllllllllll}1.1 & 0.2 & 1.4 & 4.0 & 3.7 & 3.3 & (2.0) & (2.4) & 2.8 & 1.2 & (3.7) & 0.3 & 1.4\end{array}$

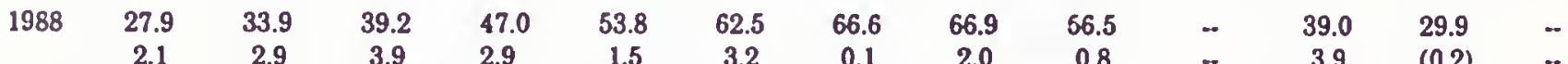

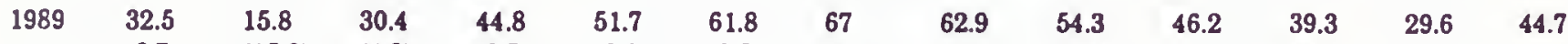

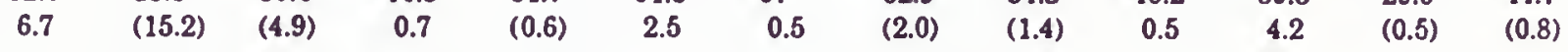

$\begin{array}{cccccccccccccc}1990 & 33.8 & 30.6 & 36.4 & 46.2 & 49.7 & 57.7 & 66.5 & 65.6 & 61.9 & \ldots & \ldots & \ldots & . .\end{array}$

\footnotetext{
** FIRST LINE CONTAINS AVERAGES, SECOND LINE CONTAINS DEPARTURES FROM NORMAL (1951-1980) - INDICATES MISSING DATA FOR THAT MONTH

NUMBERS IN PARENTHESES () ARE NEGATTVE VALUES
} 


\section{FIGURE 3}

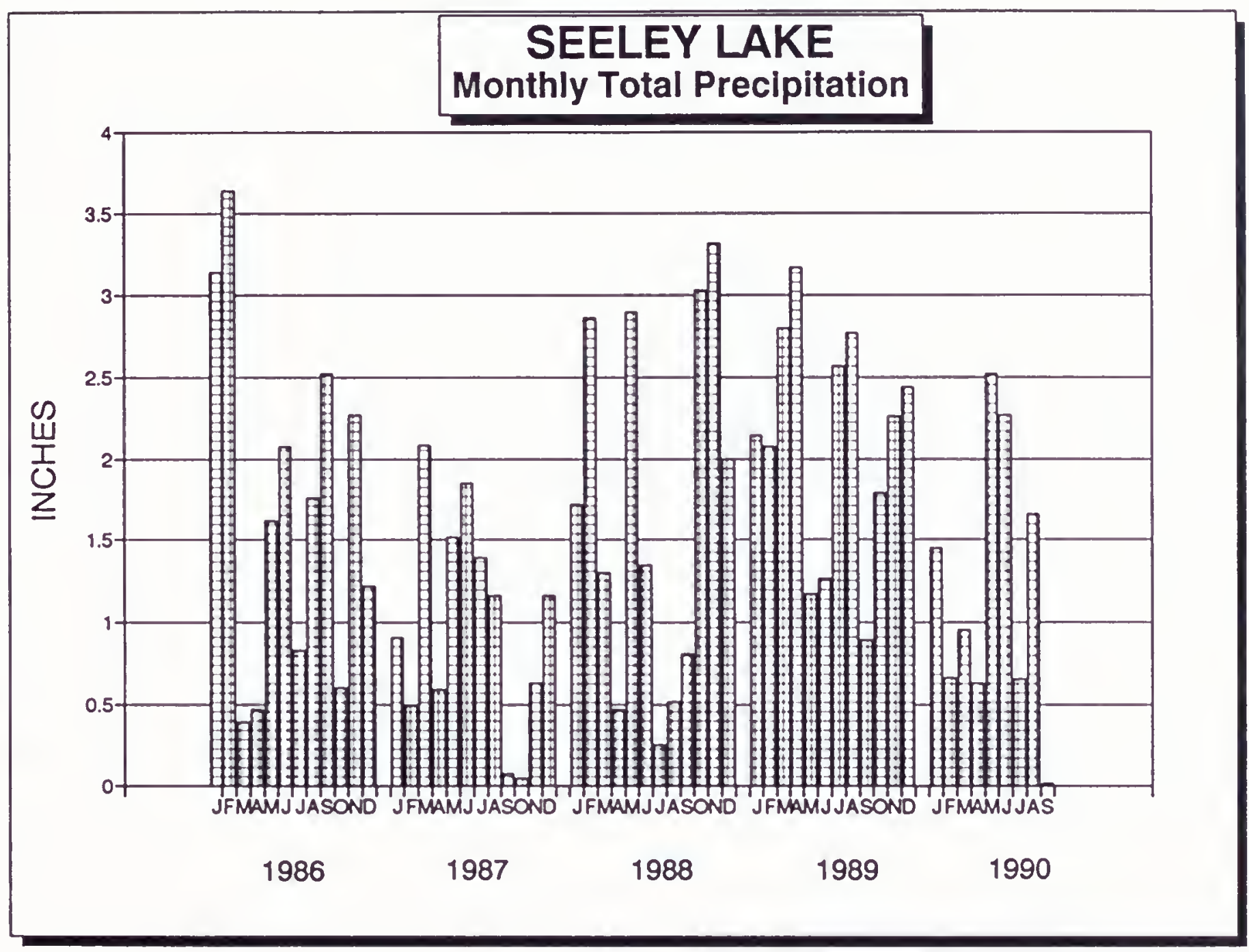

\section{SEELEY LARE PRECIPITATION DATA **}

$\begin{array}{llllllllllllll}\text { YEAR } & \text { JAN } & \text { FEB } & \text { MAR } & \text { APR } & \underline{\text { MAY }} & \underline{\text { JUN }} & \underline{\text { JU }} & \underline{\text { AUG }} & \underline{\text { SEP }} & \underline{\text { OCT }} & \underline{\text { NOV }} & \underline{\text { DEC }} & \text { TOT } \\ 1986 & 3.14 & 3.64 & 0.39 & 0.47 & 1.62 & 2.07 & 0.83 & 1.76 & 2.52 & 0.60 & 2.27 & 1.22 & 20.53 \\ & (0.11) & 1.80 & (1.28) & (0.91) & (0.29) & (0.12) & (0.13) & (0.59) & 1.18 & (0.71) & \cdots & (1.77) & \cdots \\ 1987 & 0.91 & 0.49 & 2.08 & 0.59 & 1.52 & 1.85 & 1.39 & 1.16 & 0.07 & 0.04 & 0.63 & 1.16 & 11.89 \\ & - & (1.35) & 0.41 & (0.79) & (0.39) & (0.34) & 0.43 & (0.01) & (1.27) & (1.27) & (1.47) & (1.83) & \cdots \\ 1988 & 1.72 & 2.86 & 1.30 & 0.47 & 2.90 & 1.35 & 0.25 & 0.51 & 0.81 & 3.03 & 3.32 & 2.00 & 20.52 \\ & (1.53) & 1.02 & (0.37) & (0.91) & 0.99 & (0.84) & (0.71) & (0.66) & (0.53) & 1.72 & 1.22 & (0.99) & (1.59) \\ 1989 & 2.14 & 2.07 & 2.80 & 3.17 & 1.17 & 1.26 & 2.57 & 2.77 & 0.89 & 1.79 & 2.26 & 2.44 & 25.33 \\ & (1.11) & (0.23) & 1.13 & 1.79 & (0.74) & (0.93) & 1.61 & 1.60 & (0.45) & 0.48 & 0.16 & (0.55) & 3.22 \\ 1990 & 1.45 & 0.66 & 0.95 & 0.63 & 2.52 & 2.27 & 0.65 & 1.66 & 0.01 & - & - & - & \cdots \\ & (1.80) & (1.18) & 0.95 & (0.75) & 0.61 & 0.08 & (0.31) & 0.49 & (1.33) & & & & \end{array}$

** FIRST LINE CONTAINS TOTALS, SECOND LINE CONTAINS DEPARTURES FROM NORMAL (1951-1980) 
FIGURE 4

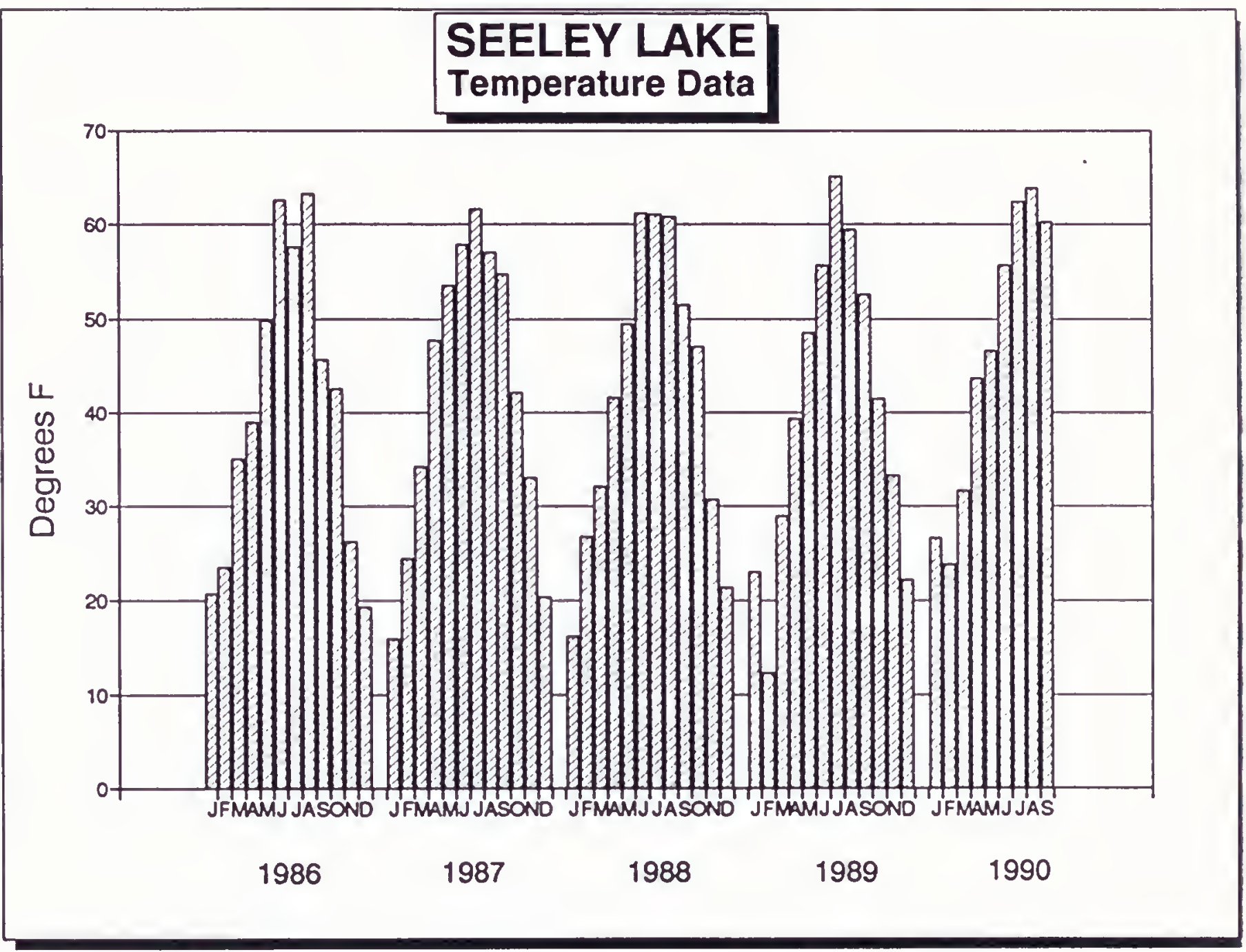

SEELEY LARE TEMPERATURE DATA *

$\begin{array}{llllllllllllll}\text { YEAR } & \text { JAN } & \text { FEB } & \text { MAR } & \text { APR } & \underline{\text { MAY }} & \underline{\text { JUN }} & \underline{\text { JUL }} & \underline{\text { AUG }} & \underline{\text { SEP }} & \underline{\text { OCT }} & \underline{\text { NOV }} & \underline{\text { DEC }} & \text { TOT } \\ 1986 & 20.6 & 23.4 & 35.0 & 38.9 & 49.8 & 62.5 & 57.5 & 63.2 & 45.6 & 42.5 & 26.2 & 19.3 & 40.4 \\ & 1.2 & (3.0) & 4.7 & (0.9) & 1.0 & 6.4 & (4.7) & 2.1 & (7.5) & (1.5) & (5.0) & (3.8) & (0.9) \\ 1987 & 15.9 & 24.4 & 34.1 & 47.6 & 63.5 & 57.8 & 61.5 & 57.0 & 54.6 & 42.1 & 32.9 & 20.4 & 41.8 \\ & (3.5) & (2.0) & 3.8 & 7.8 & 4.7 & 1.7 & (0.9) & (4.1) & 1.5 & (1.9) & 1.7 & (2.7) & 0.5 \\ 1988 & 16.1 & 26.7 & 31.9 & 41.6 & 49.4 & 61.1 & 61.0 & 60.8 & 51.4 & 46.9 & 30.6 & 21.3 & 41.6 \\ & (3.3) & 0.3 & 1.6 & 1.8 & 0.6 & 5.0 & (1.4) & (0.3) & (1.7) & 2.9 & (0.6) & (1.8) & 0.3 \\ 1989 & 22.9 & 12.2 & 28.9 & 39.3 & 48.4 & 55.6 & 65.1 & 59.4 & 52.5 & 41.4 & 33.2 & 22.1 & 40.1 \\ & 3.5 & (14.2) & (1.4) & (0.5) & (0.4) & (0.5) & 2.7 & (1.7) & (0.6) & (2.6) & 2.0 & (1.0) & (1.2) \\ 1990 & 26.6 & 23.7 & 31.6 & 43.6 & 46.5 & 55.6 & 62.3 & 63.9 & 60.2 & -. & - & - & -\end{array}$

- FIRST LINE CONTAINS AVERAGES, SECOND LINE CONTAINS DEPARTURES FROM NORMAL (1951-1980) - INDICATES MISSING DATA FOR THAT MONTH

NUMBERS IN PARENTHESES () ARE NEGATIVE VALUES 
The goals of the monitoring program were to determine the best method of tracking $\underline{H}$. aquatilis populations over time, and to determine population trends with respect to management practices. ocular population size estimates and percent cover of $\underline{H}$. aquatilis within ponds appears to be the most suitable measure for several reasons: 1) it is an easy, fast, and simple way of sampling a large number of ponds and, 2) it causes the least disturbance within populations. The drawback to population estimation by this method is the difficulty of determining exact numbers of individuals when they are clumped, or in great enough numbers to be difficult to count.

Although cover gives a better measure of plant biomass than does number of individuals present, the line-intersect measurements are very time consuming for a small number of samples, and the disturbance caused by reading the transects is significant. This disturbance physically uproots the delicate $\underline{H}$. aquatilis plants and other species within the pond, and probably affects subsequent transect readings.

In 1989 and 1990, frequency measurements were also added to the transect study of $\underline{H}$. aquatilis. The frequency plots also indicated a reduction in estimated population sizes from 19891990, similar to but less severe than results given by the ocular population estimates and line-transect study.

In conclusion, for long-term monitoring of $\underline{H}$. aquatilis, ocular population size estimation is the recommended method of study. Frequency measurements can also be used to quantitatively track population shifts from year to year, but repeated wading along the transect 1 ines is required.

As hypothesized by Lesica (1990), the large population size fluctuations may be due to variation in pond drying times. Additional data regarding the actual dates of pond drying, are needed to more closely determine the nature of the observed fluctuations.

\section{TRANSPLANT EXPERIMENTS}

METHODS: During september of 1989, soil plugs for transplant experiments were obtained from two ponds containing dense populations of $\underline{H}$. aquatilis. The transplants were placed in four ponds that appeared to contain suitable habitat for $\underline{H}$. aguatilis, but that had not been observed to support the species. Methods for the transplant study are described in shelly and schassberger (1990). The first year of quantitative monitoring of the four transplant ponds was completed. The geographic locations and elevations of the transplant ponds are: 


\begin{tabular}{|c|c|c|c|c|c|c|}
\hline Pond & & COWNSHIP, & RANGE, $S$ & $E C$, & QTR SEC & ELEVATION \\
\hline 0. & • & KI & & & $W \frac{1}{4} ;$ & $8 \mathrm{~m}$ (3 \\
\hline & . & J RI & on & 2 & 942 & $1 \mathrm{~m}(309$ \\
\hline OND & C. & P19N R17W & tion & 12 & NV & $1295.7 \mathrm{~m} / 42$ \\
\hline DND & D.j & T19N R17W & section & 12, & $S W \div S E \frac{1}{4} N W \frac{2}{4}$ & $1291.2 \mathrm{~m}$ \\
\hline
\end{tabular}

The locations of these transplant sites are shown maps on pp. 1617.

Transects at ponds A and $B$ were read on $18 \mathrm{July} 1990$, and at ponds C and D on 19 July 1990. Transects were read by carefully wading out into the pond and visually searching along the length of the tape for $\underline{H}$. aquatilis plants. After reading the transect, the rest of the area near the transect and the rest of the pond were searched for $\underline{H}$. aquatilis. This ensured that any seeds of H. aquatilis in ponds $C$ and $D$ that might have floated away and established plants elsewhere were located.

RESULTS: Howellia aquatilis was present in two of the four transplant ponds ( $A$ and $B$ ) in 1991. Howellia aquatilis was not observed in ponds $C$ or $D$. Results for ponds $A$ and $B$ are as are in Table 5, p. 18, and Table 6, p. 19, respectively. Plants were located very near the points where the soil cores were placed along the tape.

DIScussIoN: As stated in the earlier report (shelly and Schassberger 1990), two of the four ponds receiving soil plugs still contained water on the transplant date ( $C$ and $D$ ), and it is unlikely that these ponds dried out much further prior to freezing. The transects in the other ponds ( $A$ and $B$ ) were not under water on the transfer date. The results of the field transplants appear to confirm the observed laboratory results

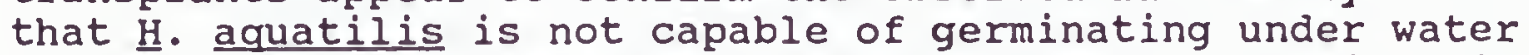
(Lesica 1990). This may help to explain why population sizes fluctuate from year to year. If ponds do not dry out in the fall of a particular year, even if fruiting and seed production are high, the seeds would not germinate and the population would be reduced in size the following year.

A small number of plants were established in transplant ponds $A$ and $B$ in 1990 ( 32 and 5 plants, respectively). Both ponds contained plants that were reproductive. However, as noted at the bottom of Tables 5 and 6 , Pond $A$ had a large number of flowering plants with submergent or emergent flowers or both, while Pond B contained only five plants with submergent flowers. While the transplants to ponds $A$ and $B$ could be considered a success in 1990 , it remains to be seen whether or not these small H. aquatilis populations are present next year or thereafter. If these transplant populations remain viable, it might be hypothesized that dispersal limitations keep $\underline{H}$. aquatilis from establishing in currently uninhabited but suitable ponds. 
Table 5. Number and location of plants in transplant pond $A$ in 1990.

POND A

Date Read: 18 July 1991

Tape

Point

(m)

1.6 Three plants: $2 \mathrm{w} /$ submergent flowers, $1 \mathrm{w} /$ both submergent and emergent flowers.

3.1 Two plants: $1 \mathrm{w} /$ submergent flowers, $1 \mathrm{w} /$ both submergent and emergent flowers.

6.0 Four plants: $3 \mathrm{w} /$ emergent flowers, 1 vegetative plant.

8.4 No plants observed.

10 One plant: w/ emergent flower.

12 No plants observed.

14 One plant: w/ submergent and emergent flowers.

16 No plants observed.

18 Four plants: all with w/ submergent flowers.

20 Three plants: large, all w/ submergent and emergent flowers.

22 Two plants: both $\mathrm{w} /$ submergent and emergent flowers.

24 Six plants: 3 uprooted, all $6 \mathrm{w} /$ submergent and emergent flowers.

26 One plant: w/ emergent flowers.

28 Two plants: both $\mathrm{w} /$ submergent and emergent flowers.

30 Three plants: $2 \mathrm{w} /$ submergent flowers, $1 \mathrm{w} /$ submergent and emergent flowers.

\section{2 plants total}

$17 \mathrm{w} /$ submergent and emergent flowers or fruits

$9 \mathrm{w} /$ only submergent flowers

5 with only emergent flowers

1 vegetative plant 
Table 6. Number and location of plants in transplant pond $B$ in 1990.

Pond $B$

Date Read: 18 July 1990

Tape Results

Point

(m)

2 One plant: w/ submergent flowers and buds.

4 One plant: w/ submergent fruits.

6 No plants observed.

8 No plants observed.

10 No plants observed.

12 One detached plant: w/ submergent buds and fruit.

13 No plants observed.

14 One plant: $w /$ submergent flower bud.

15 No plants observed.

16 No plants observed.

17 One plant: w/ submergent flowers and fruits.

20 No plants observed.

22 No plants observed.

24 No plants observed.

5 plants total

5 plants $w /$ submergent flowers, fruits or buds

0 plants $\mathrm{w} /$ emergent flowers 
On the other hand, if the transplant populations do not persist, then it is possible that transplant ponds were unsuitable for $\underline{H}$. aquatilis due to one or more environmental factors.

All four transplant ponds should be re-surveyed in 1991, and preferably through several more seasons.

\section{STUDY RECOMMENDATIONS}

During continuation of these studies in 1991, the following goals should be emphasized:

1.) estimate population size, and percent cover of $\underline{\mathrm{H}}$. aquatilis within ponds, for 26 populations.

2.) conduct studies of the pond drying dates for selected locations to determine more closely the influence that this factor may have on the abundance of $\underline{H}$. aquatilis in the subsequent year.

3.) monitor the transplant locations (2nd year).

4.) survey ponds that have suitable habitat in the Lake Five area near West Glacier, Montana.

5.) Continue frequency studies in the five ponds containing line transects. 
VII. ELEMENT OCCURRENCE PRINT-OUTS AND MAPS: NEW SITES 
Occurrence number: 058

Global rank: $\mathrm{G} 2$

state rank: $\mathrm{s} 2$

Survey site name:

EO rank:

EO rank comments:
Forest Service status: SENSITIVE LIST Federal status: Cl

SALMON PRAIRIE

$B C$

SMALL POPULATION, SOME PHALARIS ON

MARGINS; ONLY I POND. LITTLE EVIDENCE OF RECENT DISTURBANCE.

county: LAKE

USGS quadrangle: SALMON PRAIRIE

Township-range: 022N017W Section: 16 Precision: $\mathrm{S}$ Township-range comments: CENTER

Survey date: 1990-08-27

First observation: 1990

Last observation: 1990-08-27
Elevation: 3555

Slope/aspect: LEVEL

size (acres): 1

Location:

CA. 2.4 AIR MILES NORTH OF SALMON PRAIRIE. NORTH OF SALMON PRAIRIE

TAKE STATE HWY. 83 NORTH CA. 1.5 MILES TO F.S. ROAD \#9769. GO EAST CA.

0.5 MILE; POND IS NORTH OF ROAD CA. 0.5 MILE.

Element occurrence data:

1I-50 PLANTS IN FRUIT (SEE COMMENTS).

General site description:

SMALL GLACIAL POTHOLE SURROUNDED BY DOUGLAS FIR-LARCH-LODGEPOLE

FOREST. PEAT SUBSTRATE. POND VEGETATION IS CAREX VESICARIA, SIUM

SUAVE, POTAMOGETON GRAMINEUS.

Land owner/manager:

PRIVATELY OWNED LAND (INDIVIDUAL OR CORPORATE)

Comments:

BAD YEAR (1990) FOR HOWELLIA; LATE SEASON COUNTS UNRELIABLE.

Information source:

LESICA, P. DIVISION OF BIOLOGICAL SCIENCES, UNIV. OF MONTANA, MISSOULA, MT 59812 . 
Occurrence number: 059

Global rank: G2

state rank: $\mathbf{S 2}$
Forest Service status: SENSITIVE LIST

Federal Status: $\mathrm{Cl}$

Survey site name: LOST CREEK - CILLY CREEK PONDS

EO rank: C

EO rank comments: SMALL POND, VERY SHALIOW, LARGE AREAS OF CAREX VESICARIA.

County: LAKE

USGS quadrangle: CILLY CREEK

Township-range: 024N017W Section: 07 Precision: S Township-range comments: SE4SE4NE4, NE4NE4SE4

Survey date: 1990-07-17 Elevation: 3235

First observation: $1990 \quad$ Slope/aspect:

Last observation: 1990-07-17 Size (acres): 1

Location:

SWAN VALLEY, 0.61 AIR MILE EAST OF STATE HWY. 83, 0.18 AIR MILE NORTH OF CILLY CREEK, AND CA. 5 AIR MILES SSE OF SWAN LAKE (TOWN).

Element occurrence data:

CA. 150 PLANTS, 80\% OF WHICH ARE ALONG A LOG IN CENTER OF POND.

General site description:

SMALL POND (CA. $30 \mathrm{~m} \times 70 \mathrm{~m}$ ), DOMINATED BY CAREX VESICARIA; MORE OPEN AREAS WITH SIUM SUAVE. EDGE OF POND SURROUNDED BY LARGE COTTONWOODS, WILLOW, ALDER, AND PAPER BIRCH. POND IS LESS THAN 2 FT. DEEP.

Land owner/manager:

FLATHEAD NATIONAL FOREST, SWAN LAKE RANGER DISTRICT

Comments:

SIGHT RECORD - NO VOUCHER SPECIMEN.

Information source:

SCHASSBERGER, L.A. MONTANA NATURAL HERITAGE PROGRAM, 1515 E. SIXTH AVENUE, HELENA, MT 59620. 
VIII. ELEMENT OCCURRENCE PRINT-OUTS: RESURVEYED SITES 
Occurrence number: 001

Global rank: G2 Forest Service status: SENSITIVE LIST

state rank: $\mathrm{S2}$

Federal status: $\mathrm{Cl}$

Survey site name: LINDBERGH LAKE

EO rank: D

EO rank comments: SMALL POPULATION; NORTH MARGIN OF POND

IMPACTED BY LOGGING.

county: MISSOULA

USGS quadrangle: CYGNET LAKE

Township-range: 019N017W Section: 12 Precision: S

Township-range comments: NE4SE4NW4

Survey date: 1984-07-15

First observation: 1984

Last observation: 1990-07-19
Elevation: 4230

Slope/aspect: LEVEL

size (acres): 2

Location:

SWAN VALLEY, 0.68 AIR MILES NNE. FROM THE FIRST FORK ON LINDBERGH LAKE ROAD, CA. 2.5 MILES WEST FROM ST. HWY. 83.

Element occurrence data:

1990: 27 PLANTS; 1989: 300-400 PLANTS; 1987: EST. 75-100+ PLANTS;

NORTH END OF POND IMPACTED BY LOGGING, WITH SOME SLASH PILED INTO THE

WATER.

General site description:

GIACIAL POTHOLE; WITH CAREX VESICARIA, SIUM SUAVE, RANUNCULUS

GMELINII; POPULUS TRICHOCARPA, PINUS CONTORTA, LARIX OCCIDENTALIS, SALIX SP. AROUND POND.

Land owner/manager:

FLATHEAD NATIONAL FOREST, SWAN LAKE RANGER DISTRICT

Comments:

Information source:

SCHASSBERGER, L. A. 1990. MONITORING AND FIELD SURVEYS OF 10-13 AND 17-19 JULY (HOWELLIA AQUATILIS). 
Occurrence number: 006

Global rank: $\mathrm{G} 2$

state rank: $\mathbf{S 2}$
Forest Service status: SENSITIVE LIST

Federal status: Cl

Survey site name: CONDON CREEK

EO rank: C

EO rank comments: LARGE POPULATION; AREA THREATENED BY LOGGING .

county: MISSOULA

USGS quadrangle: CONDON

Township-range: $021 \mathrm{~N} 016 \mathrm{~W}$ Section: 18 Precision: S

Township-range comments: NE4NW4SW4

Survey date: 1986-07-14

First observation: 1986

Last observation: 1990-07-11
Elevation: 3740

Slope/aspect: LEVEL

size (acres): 1

Location:

SWAN VALLEY, WEST BASE OF SWAN RANGE UPLIFT, 3.5 AIR MILES NORTH OF CONDON, 2.1 AIR MILES EAST OF ST. HWY. 83, 0.1 AIR MILES SOUTH OF CONDON CREEK.

Element occurrence data:

1990: 500-1000 PLANTS; 1989 AND 1987: EST. 1000-2000 PLANTS (MANY PLANTS DISTURBED BY MOOSE AND/OR WATERFOWL ACTIVITY); AREA IS ACTIVELY THREATENED BY LOGGING ROAD CONSTRUCTION AND TIMBER HARVESTING.

General site description:

VERNAL POND, IN PINUS PONDEROSA/LARIX OCCIDENTALIS FOREST; WITH SIUM SUAVE, CAREX VESICARIA, RANUNCULUS AQUATILIS, VERONICA CATENATA, CALLITRICHE HETEROPHYLLA.

Land owner/manager:

FLATHEAD NATIONAL FOREST, SWAN LAKE RANGER DISTRICT

Comments:

VOUCHER-LESICA，P. (3965)， 1986，SPECIMEN \#104450 (MONTU).

Information source:

SCHASSBERGER, L. A. 1990. MONITORING AND FIELD SURVEYS OF 10-13 AND 17-19 JULY (HOWELLIA AQUATILIS). 
Occurrence number: 007

Global rank: G2

state rank: $\mathrm{s} 2$

Survey site name:

EO rank:

EO rank comments:
Forest Service status: SENSITIVE LIST

Federal status: $\mathrm{Cl}$

SWAN RIVER WEST

$A B$

VERY LARGE POPULATION; NEARBY STATE LAND IS LOGGED.

County: LAKE

USGS quadrangle: CILLY CREEK

Township-range: 024N018W Section: 14 Precision: S Township-range comments: SW4SE4SE4

Survey date: 1987-07-01

First observation: 1987

Last observation: 1990-07-17
Elevation: 3190

Slope/aspect: LEVEL

size (acres): 1

Location:

WEST SIDE OF SWAN VALLEY, 1.4 AIR MILES WEST OF ST. HWY. $83 ; 0.57$ AIR

MILE WEST OF SWAN RIVER; CA. 6.5 AIR MILES SOUTH OF SWAN LAKE (TOWN).

Element occurrence data:

1990: 500-1000 PLANTS; 1989: 1000-2000 PLANTS; 1987: ABOUT 3000-4000

PLANTS, POSSIBLY MORE PLANTS; VERY DENSE, AND FORMING MATS, IN WEST

POND; THE TWO PONDS, WHICH ARE SEPARATED BY A SALIX BORDER, ARE JOINED

BY HIGHER WATER IN THE SPRING.

General site description:

IN TWO SMALL, ADJACENT GLACIAL POTHOLES, IN 1-2 FEET OF WATER; WITH CAREX VESICARIA, EQUISETUM FLUVIATILE, SIUM SUAVE; POPULUS

TRICHOCARPA, BETULA PAPYRIFERA AROUND PONDS.

Land owner/manager:

FLATHEAD NATIONAL FOREST, SWAN LAKE RANGER DISTRICT

Comments:

VOUCHER-SHELLY, J.S. $(1356), 1987$, MONTU. $\mathrm{pH}=7.20$ IN WEST POND.

Information source:

SCHASSBERGER, L. A. 1990. MONITORING AND FIELD SURVEYS OF 10-13 AND 17-19 JULY (HOWELLIA AQUATILIS). 
Occurrence number: 008

Global rank: G2 state rank: 52

Survey site name: EO rank: EO rank comments:
Forest Service status: SENSITIVE LIST Federal Status: Cl

LOST CREEK-CILLY CREEK PONDS

$B$

LARGE, VIGOROUS POPULATION; IN GOOD CONDITION HABITAT.

County: LAKE

USGS quadrangle: CILLY CREEK

Township-range: $024 \mathrm{~N} 017 \mathrm{~W}$ section: 06 Precision: S Township-range comments: N2SE4

$$
\text { Survey date: 1987-07-07 }
$$

First observation: 1987

Last observation: 1990-07-18
Elevation: 3190

Slope/aspect: LEVEL Size (acres): 2

Location:

SWAN VALLEY, CA. 4.5 AIR MILES SSE. OF SWAN LAKE (TOWN); 0.5 AIR MILES EAST OF ST. HWY. 83;0.5 AIR MILES SSE. OF CONFLUENCE OF NORTH AND SOUTH FORKS LOST CREEK.

Element occurrence data:

1990: 40+ PLANTS; 1989: 1000-1500 PLANTS; 1987: EST. 2000-3000 PLANTS, IN A SINGLE POND; SURROUNDED BY A RELATIVELY UNDISTURBED FOREST, WHICH WAS REPORTEDLY LIGHTLY SELECTIVELY LOGGED IN ABOUT 1910.

General site description:

THROUGHOUT A GLACIAL POTHOLE POND, BOTTOM SOIL OF CONSOLIDATED CLAY MUCK; WITH SIUM SUAVE, RANUNCULUS AQUATILIS, GLYCERIA BOREALIS, CAREX VESICARIA, POTAMOGETON, ELEOCHARIS.

Land owner/manager:

FLATHEAD NATIONAL FOREST, SWAN LAKE RANGER DISTRICT

comments:

VOUCHER-SHELLY, J.S. (1358) AND ANNE MORLEY, 1987, MONTU. pH=7.57.

Information source:

SCHASSBERGER, L. A. 1990. MONITORING AND FIELD SURVEYS OF 10-13 AND 17-19 JULY (HOWELLIA AQUATILIS). 
Occurrence number: 009

Global rank: G2

State rank: $\mathrm{S} 2$

Survey site name: EO rank: EO rank comments:
Forest Service status: SENSITIVE LIST Federal Status: $\mathrm{Cl}$

LOST CREEK-CILLY CREEK PONDS

C MEDIUM-SIZED POPULATION, ADJACENT FOREST PREVIOUSLY LOGGED.

County: LAKE

USGS quadrangle: CILLY CREEK

Township-range: 024 N017W Section: 07 Precision: S Township-range comments: NE4NE4NE4

Survey date: 1987-07-01

First observation: 1987

Last observation: 1990-07-09
Elevation: 3250

Slope/aspect: LEVEL

Size (acres): 3

Location:

SWAN VALLEY, 0.6 AIR MILES EAST OF ST. HWY. 83, 0.6 AIR MILES SOUTH OF SOUTH FORK LOST CREEK, CA. 5.0 AIR MILES SSE OF SWAN LAKE (TOWN).

Element occurrence data:

1990: 250 PLANTS (SEVERAL AREAS HIGH COVER OF LEMNA MINOR); 1989:

500-1000 PLANTS (SPECIES DOES NOT OCCUPY ALL OF THE AVAILABLE, SUITABLE HABITAT AT THIS SITE); 1987: EST. 500-600 PLANTS; AREAS

AROUND SOUTH AND EAST SIDES OF POND, CLEARCUT CA. 15 YEARS AGO.

General site description:

IN SHALLOW WATER OF A GLACIAL POND, ORGANIC CLAY BOTTOM; WITH

EQUISETUM FLUVIATILE, CAREX VESICARIA, SIUM SUAVE; POPULUS TRICHOCARPA BORDERING POND.

Land owner/manager:

FLATHEAD NATIONAL FOREST, SWAN LAKE RANGER DISTRICT

Comments:

VOUCHER-SHELLY, J.S. (1357) AND ANNE MORLEY, 1987, MONTU.

Information source:

SCHASSBERGER, L. A. 1990. MONITORING AND FIELD SURVEYS OF 10-13 AND 17-19 JULY (HOWELLIA AQUATILIS). 
Occurrence number: 012

Global rank: $\mathrm{G} 2$

state rank:

$\mathrm{S} 2$

Forest Service status: SENSITIVE LIST

Federal status: Cl

Survey site name:

EO rank:

EO rank comments:

LOST CREEK-CILLY CREEK PONDS

C

MODERATE-SIZED POPULATION; SURROUNDING

FOREST LOGGED.

\section{county: LAKE}

USGS quadrangle: CILLY CREEK

Township-range: 024 N0I7W Section: 08 Precision: S Township-range comments: NE4SW4NW4, SE4NW4NW4

$\begin{array}{lll}\text { Survey date: } & 1987-07-07 & \text { Elevation: } 3235 \\ \text { First observation: } & 1987 & \text { Slope/aspect: LEVEL } \\ \text { Last observation: } & 1990-07-12 & \text { Size (acres): }\end{array}$

Location:

SWAN VALLEY, 0.83 AIR MILES EAST OF ST. HWY 83, 0.37 AIR MILES NORTH OF CILLY CREEK, CA. 5.0 AIR MILES SSE OF SWAN LAKE (TOWN).

Element occurrence data:

1990: EST. 35 PLANTS (Nuphar VERY ABUNDANT, H. AQUATILIS SCATTERED AMONG SIUM SUAVE); 1989: 16 PLANTS; 1987: EST. 400-500 PLANTS; MUCH OF POND HAS NO VEGETATION; LOGGING HAS OCCURRED AROUND POND.

General site description:

IN SHALLOW WATER OF A GLACIAL DEPRESSION, SOILS FAIRLY UNCONSOLIDATED; WITH NUPHAR VARIEGATUM, SIUM SUAVE, POTAMOGETON SP., POPULUS

TRICHOCARPA, BETULA PAPYRIFERA AROUND POND.

Land owner/manager:

FLATHEAD NATIONAL FOREST, SWAN LAKE RANGER DISTRICT

Comments:

SIGHT RECORD, NO VOUCHER SPECIMEN COLLECTED; SITE SURVEYED WITH ANNE MORLEY (SWAN LAKE, MT).

Information source:

SCHASSBERGER, L. A. 1990. MONITORING AND FIELD SURVEYS OF 10-13 AND 17-19 JULY (HOWELLIA AQUATILIS). 
Occurrence number: 013

Global rank: G2 Forest Service status: SENSITIVE LIST

State rank: S2 Federal Status: Cl

Survey site name: LOST CREEK-CILLY CREEK PONDS

EO rank: C

EO rank comments: LARGE POPULATION; SURROUNDING FOREST

LOGGED.

county: LAKE

USGS quadrangle: CILLY CREEK

Township-range: 024N017W Section: 08 Precision: S

Township-range comments: N2SW4NW4

Survey date: 1987-07-07 Elevation: 3240

First observation: 1987 Slope/aspect: LEVEL

Last observation: 1990-07-19 Size (acres): 2

Location:

SWAN VALLEY, 0.79 AIR MILES EAST OF ST. HWY 83, 0.36 AIR MILES NORTH OF CIILY CREEK, CA. 5.0 AIR MILES SSE OF SWAN LAKE (TOWN).

Element occurrence data:

1990: 33 PLANTS; 1989: 500-1000 PLANTS; 1987: EST. 1000-1500 PLANTS; LOGGING HAS OCCURRED AROUND POND.

General site description:

IN SHALLOW WATER OF A GLACIAL DEPRESSION; OPENINGS AMONG CAREX

VESICARIA, WITH SIUM SUAVE, ELEOCHARIS PALUSTRIS, CAREX ROSTRATA;

POPULUS TRICHOCARPA, BETULA PAPYRIFERA AROUND POND

Land owner/manager:

FLATHEAD NATIONAL FOREST, SWAN LAKE RANGER DISTRICT

Comments:

VOUCHER - SHELLY, J.S. (1359) AND ANNE MORLEY, 1987, MONTU.

Information source:

SCHASSBERGER, L. A. 1990. MONITORING AND FIELD SURVEYS OF 10-13 AND 17-19 JULY (HOWELLIA AQUATILIS). 
Occurrence number: 014

Global rank: G2 Forest service status: SENSITIVE LIST

state rank: S2 Federal status: C1

Survey site name: LOST CREEK-CILLY CREEK PONDS

EO rank: C

EO rank comments: MODERATE-SIZED POPULATION; SURROUNDING

FOREST LOGGED.

county: LAKE

USGS quadrangle: CILLY CREEK

Township-range: $024 \mathrm{~N} 017 \mathrm{~W}$ section: 08 Precision: $S$ Township-range comments: NW4SW4NW4

Survey date: 1987-07-07 Elevation: 3245

First observation: 1987 Slope/aspect: LEVEL

Last observation: 1990-07-12 Size (acres): 2

Location:

SWAN VALLEY, 0.68 AIR MILES EAST OF ST. HWY 83, 0.44 AIR MILES NORTH OF CILLY CREEK, CA. 5.0 AIR MILES SSE OF' SWAN LAKE (TOWN).

Element occurrence data:

1990: 150-250 PLANTS (SEVERAL AREAS OF DENSE POTAMOGETON); 1989: 500+ PLANTS; 1987 : EST. 300-400 PLANTS; LOGGING HAS OCCURRED IN ADJACENT FORESTS.

General site description:

IN SHALLOW WATER OF A GLACIAL DEPRESSION; AROUND LOGS \& IN OPENINGS AMONG CAREX VESICARIA, WITH SIUM SUAVE, POTAMOGETON SPP; POPULUS TRICHOCARPA, P. TREMULOIDES, BETULA PAPYRIFERA.

Land owner/manager:

FLATHEAD NATIONAL FOREST, SWAN LAKE RANGER DISTRICT

Comments :

SIGHT RECORD, NO VOUCHER SPECIMEN COLLECTED; SITE SURVEYED WITH ANNE MORLEY (SWAN LAKE, MT) ; $\mathrm{pH}=7.00$.

Information source:

SCHASSBERGER, L. A. 1990. MONITORING AND FIELD SURVEYS OF 10-13 AND 17-19 JULY (HOWELLIA AQUATILIS). 
Occurrence number: 016

Global rank: G2

state rank: s2
Forest Service status: SENSITIVE LIST

Federal Status: $\mathrm{Cl}$

Survey site name: LOST CREEK-CILIY CREEK PONDS

EO rank: C

EO rank comments: MODERATE-SIZED POPULATION; ADJACENT TO LOGGING ROAD.

County: LAKE

USGS quadrangle: CILLY CREEK

Township-range: 024 N017W Section: 07 Precision: S

Township-range comments: SE4SE4NE4, NE4NE4SE4

$\begin{array}{rll}\text { Survey date: } & 1987-07-07 & \text { Elevation: } 3235 \\ \text { First observation: } & 1987 & \text { Slope/aspect: } \\ \text { Last observation: } & 1990-07-12 & \text { Size (acres): } 2\end{array}$

Location:

SWAN VALLEY, 0.61 AIR MILES EAST OF ST. HWY 83, 0.18 AIR MILES NORTH

OF CILLY CREEK, CA. 5.0 AIR MILES SSE OF SWAN LAKE (TOWN).

Element occurrence data:

1990: 300-500 PLANTS (CAREX VESICARIA VERY DENSE; H. AQUATILIS ONLY IN

SHALLOW OPEN WATER AT EDGES OF POND, EMERGENT FLOWERS) 1989: 1000-1500

PLANTS; 1987: EST. 400+ PLANTS; ADJACENT TO LOGGING ROAD.

General site description:

IN SHALLOW WATER OF A GLACIAL DEPRESSION; WITH CAREX VESICARIA, SIUM SUAVE; POPULUS TRICHOCARPA BORDERING POND.

Land owner/manager:

FLATHEAD NATIONAL FOREST, SWAN LAKE RANGER DISTRICT

comments:

SIGHT RECORD, NO VOUCHER SPECIMEN COLLECTED; SITE SURVEYED WITH ANNE MORLEY (SWAN LAKE, MT).

Information source:

SCHASSBERGER, L. A. 1990. MONITORING AND FIELD SURVEYS OF 10-13 AND 17-19 JULY (HOWELLIA AQUATILIS). 
Occurrence number: 017

Global rank: $\mathrm{G} 2$ state rank: $\mathrm{S2}$

Survey site name: EO rank: EO rank comments:
Forest Service status: SENSITIVE LIST

Federal status: $\mathrm{Cl}$

LOST CREEK-CILLY CREEK PONDS

D

SMALL POPULATION: ADJACENT TO LOGGING ROAD.

County: LAKE

USGS quadrangle: CILLY CREEK

Township-range: 024 N017W Section: 08 Precision: S Township-range comments: SW4SW4NW4

Survey date: 1987-07-07 Elevation: 3245

First observation: 1987

Last observation: 1990-07-12
Slope/aspect: LEVEL

Size (acres): 3

Location:

SWAN VALLEY, 0.71 AIR MILES EAST OF ST. HWY 8.3, 0.25 AIR MILES NORTH OF CILLY CREEK, CA. 5.0 AIR MILES SSE OF SWAN LAKE (TOWN).

Element occurrence data:

1990: O PLANTS (WATER POSSIBLY TOO DEEP, CAREX VESICARIA DENSE); 1989 : 10-20; 1987: EST. 10-12 PLANTS; ADJACENT TO LOGGING ROAD; THIS DEPRESSION WAS MUCH DRYER THAN THE OTHERS, HOWELLIA AQUATILIS PRESENT IN A FEW PUDDLES; HABITAT MAY BE MORE ADVANCED SUCCESSIONALLY THAN NEARBY PONDS.

General site description:

IN SHALLOW WATER OF A GLACIAL DEPRESSION; WITH CAREX VESICARIA, SIUM SUAVE, POTAMOGETON, CAREX ROSTRATA, POTENTILLA PALUSTRIS; POPULUS TREMULOIDES AROUND POND.

Land owner/manager:

FLATHEAD NATIONAL FOREST, SWAN LAKE RANGER DISTRICT

Comments:

SIGHT RECORD; NO VOUCHER SPECIMEN COLLECTED; SITE SURVEYED WITH ANNE MORLEY (SWAN LAKE, MT).

Information source:

SCHASSBERGER, L. A. 1990. MONITORING AND FIELD SURVEYS OF 10-13 AND 17-19 JULY (HOWELLIA AQUATILIS). 
Occurrence number: 020

Global rank: $G 2$ state rank: $\mathrm{S2}$

Survey site name: EO rank: EO rank comments:
Forest Service status: Federal status:
SENSITIVE LIST

Cl

CONDON CREEK

C

LARGE POPULATION; AREA BEING LOGGED.

County: MISSOULA

USGS quadrangle: CONDON

Township-range: 021N016W Section: 18 precision: $\mathrm{S}$ Township-range comments: SW4NE4SW4

Survey date: 1987-07-02

First observation: 1987

Last observation: 1990-07-18
Elevation: 3740

Slope/aspect: LEVEL

Size (acres): 2

Location:

SWAN VALLEY, 3.3 AIR MILES NORTH OF CONDON, 2.13 AIR MILES EAST OF ST. HWY $83,0.25$ AIR MILES SOUTH OF CONDON CREEK.

Element occurrence data:

1990: 190+ PLANTS; 1989: 1000-1500 PLANTS; 1987: EST. 1000 PLANTS; NEARBY FORESTS RECENTLY LOGGED.

General site description:

IN SHALLOW WATER OF A GLACIAL DEPRESSION; WITH SIUM SUAVE, CAREX

VESICARIA; POPULUS TRICHOCARPA, PINUS PONDEROSA, LARIX OCCIDENTALIS IN SURROUNDING FOREST.

Land owner/manager:

FLATHEAD NATIONAL FOREST, SWAN LAKE RANGER DISTRICT

Comments:

SIGHT RECORD, NO VOUCHER SPECIMEN COLLECTED. $\mathrm{pH}=7.28$.

Information source:

SCHASSBERGER, L. A. 1990. MONITORING AND FIELD SURVEYS OF 10-13 AND

17-19 JULY (HOWELLIA AQUATILIS). 
Occurrence number: 022

Global rank: G2 state rank: $\mathrm{s} 2$

Survey site name: EO rank: EO rank comments:
Forest Service status: SENSITIVE LIST

Federal Status: Cl
CONDON CREEK

C MEDIUM-SIZED POPULATION; AREA BEING LOGGED.

county: MISSOULA

USGS quadrangle: CONDON

Township-range: 021 N016W Section: 18 Precision: S Township-range comments: SW4NE4SW4

Survey date: 1987-07-02

First observation: 1987

Last observation: 1990-07-12
Elevation: 3750

Slope/aspect: LEVEL

Size (acres): I

Location:

SWAN VALLEY, 3.28 AIR MILES NORTH OF CONDON, 2.18 AIR MILES EAST OF ST. HWY $83,0.27$ AIR MILES SOUTH OF CONDON CREEK.

Element occurrence data:

1990: 60-100 PLANTS (WATER DEEP RED-YELLOW, SIUM SUAVE SPARSE); 1989: 500-1000 PLANTS; 1987: EST. 200 PLANTS; NEARBY FORESTS RECENTLY LOGGED.

General site description:

IN SHALLOW WATER OF A GLACIAL DEPRESSION; WITH SIUM SUAVE, CAREX VESICARIA; POPULUS TRICHOCARPA, PINUS PONDEROSA, LARIX OCCIDENTALIS IN SURROUNDING FOREST.

Land owner/manager:

FLATHEAD NATIONAL FOREST, SWAN LAKE RANGER DISTRICT

Comments:

SIGHT RECORD, NO VOUCHER SPECIMEN COLLECTED.

Information source:

SCHASSBERGER, L. A. 1990. MONITORING AND FIELD SURVEYS OF 10-13 AND 17-19 JULY (HOWELLIA AQUATILIS). 
Occurrence number: 023

Global rank: $\mathrm{G} 2$

state rank: $\mathrm{S} 2$
Forest Service status: SENSITIVE LIST Federal status: $\mathrm{Cl}$

Survey site name: CONDON CREEK

EO rank: C

EO rank comments: MEDIUM-SIZED POPULATION; AREA BEING LOGGED.

county: MISSOULA

USGS quadrangle: CONDON

Township-range: 021N016W Section: 18 Precision: S Township-range comments: NW4SE4SW4

$\begin{array}{rll}\text { Survey date: } & 1987-07-02 & \text { Elevation: } 3740 \\ \text { First observation: } & 1987 & \text { Slope/aspect: LEVEL } \\ \text { Last observation: } & 1990-07-10 & \text { Size (acres): } 1\end{array}$

Location:

SWAN VALLEY, 3.2 AIR MILES NORTH OF CONDON, 2.10 AIR MILES EAST OF ST. HWY $83,0.35$ AIR MILES SOUTH OF CONDON CREEK.

Element occurrence data:

1990: 20 PLANTS; 1989: 400-500 PLANTS; 1987: 3 PLANTS (1987); SEVERAL HUNDRED PLANTS OBSERVED IN 1986 BY P. LESICA; NEARBY FORESTS RECENTLY LOGGED.

General site description:

IN SHALLOW WATER OF A GLACIAL DEPRESSION; WITH SIUM SUAVE, CAREX

VESICARIA; POPULUS TRICHOCARPA, PINUS PONDEROSA, LARIX OCCIDENTALIS IN SURROUNDING FOREST.

Land owner/manager:

FLATHEAD NATIONAL FOREST, SWAN LAKE RANGER DISTRICT

Comments:

SIGHT RECORD, NO VOUCHER SPECIMEN COLLECTED.

Information source:

SCHASSBERGER, L. A. 1990. MONITORING AND FIELD SURVEYS OF 10-13 AND

17-19 JULY (HOWELLIA AQUATILIS). 
Occurrence number: 025

Global rank: G2 state rank: $\mathbf{S 2}$

Survey site name:

EO rank:

EO rank comments:
Forest Service status: SENSITIVE LIST Federal Status: $\mathrm{Cl}$
CONDON CREEK

D

SMALL POPULATION; POND MARGIN IMPACTED BY LOGGING.

County: MISSOULA

USGS quadrangle: CONDON

Township-range: $021 \mathrm{~N} 016 \mathrm{~W}$ Section: 18 Precision: S Township-range comments: S2SE4SW4

Survey date: 1987-07-02

First observation: 1987

Last observation: 1990-07-11
Elevation: 3750

Slope/aspect: LEVEL

Size (acres): 2

Location:

SWAN VALLEY, 3.08 AIR MILES NORTH OF CONDON, 2.18 AIR MILES EAST OF ST. HWY $83,0.45$ AIR MILES SOUTH OF CONDON CREEK.

Element occurrence data:

1990: O PLANTS (CAREX AND NUPHAR VERY EXTENSIVE); 1989: 100-125

PLANTS; 1987: EST. 25 PLANTS; POND MARGINS RECENTLY DISTURBED BY

LOGGING.

General site description:

IN SHALLOW WATER OF A GLACIAL DEPRESSION; WITH SIUM SUAVE, CAREX

VESICARIA; POPULUS TRICHOCARPA, PINUS PONDEROSA, LARIX OCCIDENTALIS IN SURROUNDING FOREST.

Land owner/manager:

FLATHEAD NATIONAL FOREST, SWAN LAKE RANGER DISTRICT

Comments:

SIGHT RECORD, NO VOUCHER SPECIMEN COLLECTED.

Information source:

SCHASSBERGER, L. A. 1990. MONITORING AND FIELD SURVEYS OF 10-13 AND 17-19 JULY (HOWELLIA AQUATILIS). 
Occurrence number: 026

Global rank: G2 Forest Service status: SENSITIVE LIST

state rank: S2 Federal status: C1

Survey site name: CONDON CREEK

EO rank: C

EO rank comments: MEDIUM-SIZED POPULATION; AREA BEING LOGGED.

County: MISSOULA

USGS quadrangle: CONDON

Township-range: 021N016W Section: 18 Precision: S Township-range comments: SE4NW4SW4

$\begin{array}{rll}\text { Survey date: } & 1987-07-02 & \text { Elevation: } 3710 \\ \text { First observation: } & 1987 & \text { Slope/aspect: LEVEL } \\ \text { Last observation: } & 1990-07-12 & \text { Size (acres): } 1\end{array}$

Location:

SWAN VALLEY, 3.29 AIR MILES NORTH OF CONDON, 1.97 AIR MILES EAST OF ST. HWY $83,0.28$ AIR MILES SOUTH OF CONDON CREEK.

Element occurrence data:

1990: 1000-2000 (VERY DENSE WITH MANY EMERGENT FLOWERING STEMS, ONLY MISSING FROM SHALLOW EDGES OF NORTHERN END OF POND); 1989: 500-1000 PLANTS; 1987: EST. 200-300 PLANTS; NEARBY FORESTS RECENTLY LOGGED.

General site description:

IN SHALLOW WATER OF A GLACIAL DEPRESSION; WITH SIUM SUAVE, CAREX VESICARIA; POPULUS TRICHOCARPA, PINUS PONDEROSA, LARIX OCCIDENTALIS IN SURROUNDING FOREST.

Land owner/manager:

FLATHEAD NATIONAL FOREST, SWAN LAKE RANGER DISTRICT

Comments :

SIGHT RECORD, NO VOUCHER SPECIMEN COLLECTED.

Information source:

SCHASSBERGER, L. A. 1990. MONITORING AND FIELD SURVEYS OF 10-13 AND 17-19 JULY (HOWELLIA AQUATILIS). 
Occurrence number: 027

Global rank: G2

state rank: $\mathbf{s 2}$
Forest Service status: SENSITIVE LIST

Federal Status: $\mathrm{Cl}$
Survey site name:

EO rank:

EO rank comments:
CONDON CREEK

$D$

MEDIUM-SIZED POPULATION; POND MARGIN IMPACTED BY LOGGING.

County: MISSOULA

USGS quadrangle: CONDON

Township-range: 021N016W section: 18 Precision: S Township-range comments: NW4SW4SW4

\section{Survey date: 1987-07-02}

First observation: 1987

Last observation: 1990-07-17
Elevation: 3690

Slope/aspect: LEVEL

Size (acres): 2

Location:

SWAN VALLEY, 3.18 AIR MILES NORTH OF CONDON, 1.84 AIR MILES EAST OF ST. HWY $83,0.40$ AIR MILES SOUTH OF CONDON CREEK.

Element occurrence data:

1990: 200+ PLANTS; 1989: 300-400 PLANTS; 1987: EST. 300 PLANTS; SOUTH MARGIN OF POND RECENTLY DISTURBED BY LOGGING.

General site description:

IN SHALLOW WATER OF A GLACIAL DEPRESSION; WITH SIUM SUAVE, CAREX

VESICARIA; POPULUS TRICHOCARPA, PINUS PONDEROSA, LARIX OCCIDENTALIS IN SURROUNDING FOREST.

Land owner/manager:

FLATHEAD NATIONAL FOREST, SWAN LAKE RANGER DISTRICT

Comments:

SIGHT RECORD, NO VOUCHER SPECIMEN COLLECTED. $\mathrm{pH}=7.66$.

Information source:

SCHASSBERGER, L. A. 1990. MONITORING AND FIELD SURVEYS OF 10-13 AND

17-19 JULY (HOWELLIA AQUATILIS). 
Occurrence number: 029

Global rank: $\mathrm{G} 2$ state rank: $\mathrm{S2}$
Forest Service status: SENSITIVE LIST Federal status: $\mathrm{Cl}$

Survey site name: CONDON CREEK

EO rank: D

EO rank comments: MEDIUM-SIZED POPULATION; POND MARGINS IMPACTED BY LOGGING.

county: MISSOULA

USGS quadrangle: CONDON

Township-range: 021N016W Section: 19 Precision: S Township-range comments: NW4NW4NW4

Survey date: 1987-07-02 Elevation: 3690

First observation: 1987 Slope/aspect: LEVEL Last observation: 1990-07-10 Size (acres): 2

Location:

SWAN VALLEY, 2.97 AIR MILES NORTH OF CONDON, 1.88 AIR MILES EAST OF ST. HWY 83, 0.59 AIR MILES SOUTH OF CONDON CREEK.

Element occurrence data:

1990: 100-200 PLANTS (ONLY IN VERY SHALLOW EDGE WATERS); 1989:

500-1000 PLANTS; 1987: EST. 200-300 PLANTS; POND MARGINS RECENTLY DISTURBED BY LOGGING.

General site description:

IN SHALLOW WATER OF A GLACIAL DEPRESSION; WITH SIUM SUAVE, CAREX

VESICARIA; POPULUS TRICHOCARPA, PINUS PONDEROSA, LARIX OCCIDENTALIS IN SURROUNDING FOREST.

Land owner/manager:

BURLINGTON NORTHERN LAND

Comments:

SIGHT RECORD, NO VOUCHER SPECIMEN COLLECTED.

Information source:

SCHASSBERGER, L. A. 1990. MONITORING AND FIELD SURVEYS OF 10-13 AND 17-19 JULY (HOWELLIA AQUATILIS). 
Occurrence number: 030

Global rank: G2 state rank: $\quad$ 22

Survey site name: EO rank: EO rank comments:
Forest Service status: SENSITIVE LIST Federal Status: $\mathrm{Cl}$

CONDON CREEK

D

LARGE POPULATION; POND MARGINS IMPACTED BY LOGGING.

county: MISSOULA

USGS quadrangle: CONDON

Township-range: $021 N 016 \mathrm{~W}$ Section: 19 Precision: S Township-range comments: NE4NE4NW4

Survey date: 1987-07-02

First observation: 1987

Last observation: 1990-07-12
Elevation: $\quad 3740$

Slope/aspect: LEVEL

Size (acres): I

Location:

SWAN VALLEY, 2.99 AIR MILES NORTH OF CONDON, 2.19 AIR MILES EAST OF ST. HWY $83,0.55$ AIR MILES SOUTH OF CONDON CREEK.

Element occurrence data:

1990: 0 PLANTS; 1989 AND 1987: EST. 1000 PLANTS; POND MARGINS RECENTLY DISTURBED BY LOGGING.

General site description:

IN SHALLOW WATER OF A GIACIAL DEPRESSION; WITH SIUM SUAVE, CAREX VESICARIA; POPULUS TRICHOCARPA, PINUS PONDEROSA, LARIX OCCIDENTALIS IN SURROUNDING FOREST.

Land owner/manager:

BURLINGTON NORTHERN LAND

Comments:

SIGHT RECORD, NO VOUCHER SPECIMEN COLLECTED.

Information source:

SCHASSBERGER, L. A. 1990. MONITORING AND FIELD SURVEYS OF 10-13 AND 17-19 JULY (HOWELLIA AQUATILIS). 
Occurrence number: 032

Global rank: G2 state rank: 52

Survey site name: EO rank: EO rank comments:
Forest Service status: SENSITIVE IIST Federal Status: Cl
LINDBERGH LAKE

B

MEDIUM-SIZED POPULATION; HABITAT RELATIVELY UNDISTURBED.

County: MISSOULA

USGS quadrangle: CYGNET LAKE

Township-range: 019N016W Section: 07 Precision: S Township-range comments: SE4SW4NW4

Survey date: 1983-07-24 Elevation: 4165

First observation: 1983

Last observation: 1990-07-10
Slope/aspect: LEVEL

Size (acres): 2

Location:

SWAN VALLEY, 0.16 AIR MILES SOUTH OF LINDBERGH LAKE RD., CA. 1.75 AIR MILES WEST OF ST. HWY 83 .

Element occurrence data:

1990: 3-10 PLANTS (PLANTS INTERTWINED, DIFFICULT TO ESTIMATE; FEW SIUM suave PRESENT): 1989: 750-1000 PLANTS; 1983: EST. 101-1000 PLANTS.

General site description:

GLACIAL POTHOLE, IN ONE TO TWO FEET OF WATER; WITH EQUISETUM

FLUVIATILE, SIUM SUAVE, TYPHA, CAREX ROSTRATA; POPULUS TRICHOCARPA, P. TREMULOIDES AROUND POND.

Land owner/manager:

PRIVATELY OWNED LAND (INDIVIDUAL OR CORPORATE)

Comments:

Information source:

SCHASSBERGER, L. A. 1990. MONITORING AND FIELD SURVEYS OF 10-13 AND 17-19 JULY (HOWELLIA AQUATILIS). 
Howellia aquatilis

Occurrence number: 035

Global rank: $\mathrm{G} 2$ state rank: 52

Survey site name: LINDBERGH LAKE

EO rank: B

EO rank comments: MEDIUM-SIZED POPULATION; HABITAT REIATIVELY UNDISTURBED.

county: MISSOULA

USGS quadrangle: CYGNET LAKE

Township-range: 019N016W Section: 07 Precision: S Township-range comments: E2NE4SW4

Survey date: 1983-07-24 Elevation: 4150

First observation: 1983 Slope/aspect: LEVEL

Last observation: 1990-07-10 Size (acres): 2

Location:

SWAN VALLEY, 0.38 AIR MILES SOUTH OF LINDBERGH LAKE RD., CA. 1.5 AIR MILES WEST OF ST. HWY 83.

Element occurrence data:

1990: 0 PLANTS (NO SIUM SUAVE PRESENT, WATER DEEP YELLOW RED, OILY SCUM AT SURFACE (POSSIBLY DUE TO HIGH LEAF CONTENT)); 1989: 500-750 PLANTS; 1983: EST. 51-1000 PLANTS.

General site description:

GLACIAL POTHOLE, IN 0.5-1.5 FEET OF WATER; WITH SIUM SUAVE, CAREX ROSTRATA.

Land owner/manager:

PRIVATELY OWNED LAND (INDIVIDUAL OR CORPORATE)

Comments:

Information source:

SCHASSBERGER, L. A. 1990. MONITORING AND FIELD SURVEYS OF 10-13 AND 17-19 JULY (HOWELLIA AQUATILIS). 
Occurrence number: 044

Global rank: $\mathrm{G} 2$ state rank: $\mathrm{S2}$

Survey site name: LINDBERGH LAKE

EO rank: C

EO rank comments: LARGE POPULATION; ADJACENT TO A GRAVEL ROAD.

County: MISSOULA

USGS quadrangle: CYGNET LAKE

Township-range: 019N017W Section: 12 Precision: S Township-range comments: S2SE4NE4, N2NE4SE4

$\begin{array}{rll}\text { Survey date: } & 1987-07-29 & \text { Elevation: 4215 } \\ \text { First observation: } & 1987 & \text { Slope/aspect: LEVEL } \\ \text { Last observation: } & 1990-07-10 & \text { Size (acres): } 1\end{array}$

Location:

SWAN VALLEY, SOUTHEAST OF LINDBERGH LAKE RD., 2.0 AIR MILES WEST OF ST. HWY 83.

Element occurrence data:

1990: O PLANTS (POND HAD OILY SLICK ON SURFACE, DEEP RUST COLORED WATER, VERY LITTLE SIUM SUAVE PRESENT); 1989: 90-120 PLANTS; 1987: EST. 275-400 PLANTS; POND IS ALONGSIDE A HEAVILY USED GRAVEL ROAD, AND IS UNDER A POWER LINE.

General site description:

GLACIAL POTHOLE DEPRESSION; WITH CAREX VESICARIA, SIUM SUAVE, RANUNCULUS AQUATILIS; POPULUS TRICHOCARPA, P. TREMULOIDES PINUS CONTORTA, LARIX OCCIDENTALIS AROUND POND.

Land owner/manager:

FLATHEAD NATIONAL FOREST, SWAN LAKE RANGER DISTRICT

Comments:

Information source:

SCHASSBERGER, L. A. 1990. MONITORING AND FIELD SURVEYS OF 10-13 AND 17-19 JULY (HOWELLIA AQUATILIS). 
Occurrence number: 045

Global rank: G2 Forest Service status: SENSITIVE LIST

state rank: S2 Federal status: C1

Survey site name: LINDBERGH LAKE

EO rank: C

EO rank comments: FAIRLY SMALL POPULATION, NEARBY AREAS

LOGGED.

county: MISSOULA

USGS quadrangle: CYGNET LAKE

Township-range: 019N016W Section: 18 Precision: S Township-range comments: SE4SW4SE4

Survey date: 1987-07-10 Elevation: 4250

First observation: 1987 Slope/aspect: LEVEL

Last observation: 1990-07-09 Size (acres): 2

Location:

SWAN VALLEY, 1.83 AIR MILES ESE OF NORTH END OF LINDBERGH LAKE, 1.08 AIR MILES SOUTH OF SWAN RIVER, CA. 2.0 AIR MILES WEST OF ST. HWY 83.

Element occurrence data:

1990: 10 PLANTS (HEAVY ALGAL BLOOMS, WATER RUST COLORED, WATER

APPEARED DEEPER); 1989: 300-400 PLANTS; 1987: EST. 300

General site description:

GLACIAL POTHOLE POND, SURROUNDED BY PINUS CONTORTA FOREST, POPULUS TREMULOIDES NEAR MARGIN; WITH CAREX VESICARIA, EQUISETUM FLUVIATILE, POTAMOGETON GRAMINEUS, SIUM SUAVE.

Land owner/manager:

FLATHEAD NATIONAL FOREST, SWAN LAKE RANGER DISTRICT

Comments:

VOUCHER - SHELLY, J.S. (1364) AND L. CAMPBELL, 1987, MONTU.

Information source:

SCHASSBERGER, L. A. 1990. MONITORING AND FIELD SURVEYS OF 10-13 AND

17-19 JULY (HOWELLIA AQUATILIS). 
Occurrence number: 046

Global rank: $\mathrm{G} 2$

State rank: $\mathrm{S2}$

survey site name: LINDBERGH LAKE

EO rank: D

EO rank comments: SMALL POPULATION; SURROUNDING HABITAT DISTURBED BY LOGGING.

County: MISSOULA

USGS quadrangle: CYGNET LAKE

Township-range: 019N016W section: 18 Precision: S

Township-range comments: SW4NW4NW4

$\begin{array}{rll}\text { Survey date: } & 1987-07-10 & \text { Elevation: } 4230 \\ \text { First observation: } & 1987 & \text { Slope/aspect: LEVEL } \\ \text { Last observation: } & 1990-07-09 & \text { Size (acres): } 1\end{array}$

Location:

SWAN VALLEY, 0.58 AIR MILES SOUTH OF SWAN RIVER, 2.13 AIR MILES WEST OF ST. HWY 83.

Element occurrence data:

1990: 3 PLANTS (NEAR AREA OF SIUM SUAVE); 1989: 30-50 PLANTS; 1987:

EST. 50 PLANTS; ADJACENT AREAS DISTURBED BY CLEARCUT LOGGING.

General site description:

GLACIAL POTHOLE POND; WITH SIUM SUAVE, CAREX VESICARIA, TYPHA, RANUNCULUS GMELINII, POTAMOGETON GRAMINEUS.

Land owner/manager:

FLATHEAD NATIONAL FOREST, SWAN LAKE RANGER DISTRICT

Comments :

VOUCHER - SHELLY, J.S. (1368) AND L. CAMPBELL, 1987, MONTU.

Information source:

SCHASSBERGER, L. A. 1990. MONITORING AND FIELD SURVEYS OF 10-13 AND 17-19 JULY (HOWELLIA AQUATILIS). 
Occurrence number: 047

Global rank: G2 Forest service status: SENSITIVE LIST State rank: 52 Federal status: C1

Survey site name: LINDBERGH LAKE

EO rank: C

EO rank comments: MED.-SIZED POPULATION; SURROUNDING AREA

DISTURBED BY LOGGING

county: MISSOULA

USGS quadrangle: CYGNET LAKE

Township-range: 019N016W Section: 18 Precision: S

Township-range comments: SW4NE4NW4

Survey date: 1987-07-10 Elevation: 4215

First observation: 1987 Slope/aspect: LEVEL

Last observation: 1990-07-09 Size (acres): 1

Location:

SWAN VALLEY, 0.5 AIR MILES SOUTH OF SWAN RIVER, 1.95 AIR MILES WEST OF ST. HWY 83 .

Element occurrence data:

1990: 150 PLANTS; 1989 200-300 PLANTS; 1987: EST. 200 PLANTS; POND LOCATED ON EDGE OF A CLEARCUT.

General site description:

GLACIAL DEPRESSION; WITH SIUM SUAVE, CAREX VESICARIA, TYPHA LATIFOLIA, NUPHAR VARIEGATUM, ELEOCHARIS PALUSTRIS, SPARGANIUM MINIMUM; ALNUS ON EDGES, NO POPULUS.

Land owner/manager:

FLATHEAD NATIONAL FOREST, SWAN LAKE RANGER DISTRICT

Comments:

VOUCHER - SHELLY, J.S. (1365) AND L. CAMPBELL, 1987, MONTU.

Information source:

SCHASSBERGER, L. A. 1990. MONITORING AND FIELD SURVEYS OF 10-13 AND

17-19 JULY (HOWELLIA AQUATILIS). 
Occurrence number: 048

Global rank: $\mathrm{G} 2$

State rank: $\mathrm{S2}$

Survey site name:

EO rank:

EO rank comments:
Forest Service status: SENSITIVE LIST

Federal Status: $\quad$ l

LINDBERGH LAKE

C

MED.-SIZED POPULATION; SURROUNDING AREA DISTURBED BY LOGGING

County: MISSOULA

USGS quadrangle: CYGNET LAKE

Township-range: 019N016W section: 18 Precision: S Township-range comments: SW4NE4NW4

Survey date: 1987-07-10

First observation: 1987

Last observation: 1990-07-09
Elevation: 4215

Slope/aspect: LEVEL

Size (acres): 1

Location:

SWAN VALLEY, 0.5 AIR MILES SOUTH OF SWAN RIVER, 1.89 AIR MILES WEST OF ST. HWY 83.

Element occurrence data:

1990: 0 PLANTS OBSERVED (MANY DEAD SEDGE PLANTS SOUTH END OF POND,

DEAD TYPHA IN NORTH END, WATER APPEARED DEEPER THAN IN 1989); 1989:

CA: 200 PLANTS; $1987:$ EST. 250 PLANTS; ADJACENT AREAS DISTURBED BY

CLEARCUT LOGGING.

General site description:

GLACIAL POTHOLE POND; WITH CAREX VESICARIA, SIUM SUAVE, EQUISETUM

FLUVIATILE, TYPHA LATIFOLIA.

Land owner/manager:

FLATHEAD NATIONAL FOREST, SWAN LAKE RANGER DISTRICT

Comments:

VOUCHER - SHELLY, J.S. (1366) AND L. CAMPBELL, 1987, MONTU.

Information source:

SCHASSBERGER, L. A. 1990. MONITORING AND FIELD SURVEYS OF 10-13 AND 17-19 JULY (HOWELLIA AQUATILIS). 
Occurrence number: 049

Global rank: G2 Forest Service status: SENSITIVE LIST

state rank: S2 Federal status: C1

Survey site name: LINDBERGH LAKE

EO rank: C

EO rank comments: LARGE POPULATION; ADJACENT TO NEW

LOGGING ROAD.

county: MISSOULA

USGS quadrangle: CYGNET LAKE

Township-range: 019N016W Section: 07 Precision: S Township-range comments: SW4SW4SE4

Survey date: 1987-07-10 Elevation: 4150

First observation: 1987 Slope/aspect: LEVEL

Last observation: 1990-07-09 Size (acres): 1

Location:

SWAN VALLEY, 0.16 AIR MILES SOUTH OF SWAN RIVER, 1.60 AIR MILES WEST

OF ST. HWY 83.

Element occurrence data:

1990: 200-300 PLANTS (HIGH COVER OF LEMNA MINOR IN SOME AREAS); 1989: 2000+ PLANTS; 1987: EST. 1500-2000 PLANTS; POND IS ON NORTH SIDE OF A NEWLY CONSTRUCTED LOGGING ROAD, JUST NORTH OF USFS BOUNDARY.

General site description:

GLACIAL POTHOLE POND; WITH CAREX ROSTRATA, C. VESICARIA, RANUNCULUS GMELINII, R. AQUATILIS, ALOPECURUS AEQUALIS; POPULUS SPP., ALNUS INCANA, SALIX SPP. AROUND EDGE.

Land owner/manager:

PRIVATELY OWNED LAND (INDIVIDUAL OR CORPORATE)

Comments:

VOUCHER - SHELLY, J.S. (1369) AND L. CAMPBELL, 1987, MONTU. pH=7.29.

Information source:

SCHASSBERGER, L. A. 1990. MONITORING AND FIELD SURVEYS OF 10-13 AND 17-19 JULY (HOWELLIA AQUATILIS). 
IX. MAPS OF PONDS SURVEYED WITHOUT SUCCESS 


\section{LITERATURE CITED}

Lesica, P. 1990. Habitat requirements, germination behavior and seed bank dynamics of Howellia aquatilis in the Swan Valley, Montana. Unpublished report to USDA Forest Service, Flathead National Forest, Kalispell, Montana. Conservation Biology Research, Helena, Montana. 44 pp. + appendix.

Mueller-Dombois, D. and H. Ellenberg. 1974. Aims and methods of vegetation ecology. John Wiley \& Sons Inc., New York, New York. $547 \mathrm{pp}$.

Shelly, J.S. 1988. Status review of Howellia aquatilis, U.S. Forest Service - Region 1, Flathead National Forest, Montana. Unpublished report to USDA Forest Service, Flathead National Forest, Kalispell, Montana. Montana Natural Heritage Program, Helena. $120 \mathrm{pp}$.

Shelly, J.S. 1989. Addendum to the status review of Howellia aquatilis, U.S.D.A. Forest Service - Region 1, Flathead National Forest, Montana. Unpublished report to USDA Forest Service, Flathead National Forest, Kalispell, Montana. Montana Natural Heritage Program, Helena. 17 pp.

Shelly, J.S., and R. Moseley. 1988. Report on the conservation status of Howellia aquatilis, a candidate threatened species. Unpublished report to U.S. Fish and Wildlife Service, Denver, Colorado. Montana Natural Heritage Program, Helena. $166 \mathrm{pp}$.

Shelly, J.S., and L. Schassberger. 1990. Update to the status review of Howellia aquatilis, field surveys, monitoring studies and transplant experiments. Unpublished report to USDA Forest Service, Flathead National Forest, Kalispell, Montana. $50 \mathrm{pp}$.

Reel, S., L. Schassberger, and W. Ruediger. 1989. Caring for Our Natural Community: Region 1 - Threatened, Endangered and Sensitive species Program. U.S.D.A. Forest Service, Northern Region, Wildlife and Fisheries, Missoula, Montana. 309 pp. + appendices.

U.S. Department of Agriculture, Forest Service. 1988. Sensitive plant Field Guide (Montana), Northern Region. U.S.D.A. Forest Service, Missoula, Montana. 
U.S. Department of Commerce. 1982. Monthly normals of temperature, precipitation, and heating and cooling degree days 1951-80. National Oceanic and Atmospheric Administration, Climatography of the United States No. 81 . $23 \mathrm{pp}$.

U.S. Department of Interior, Fish and Wildlife Service. 1990. Endangered and threatened wildlife and plants: Review of plant taxa for listing as endangered or threatened species. Federal Register 50 CFR Part 17: 6184-6229. 


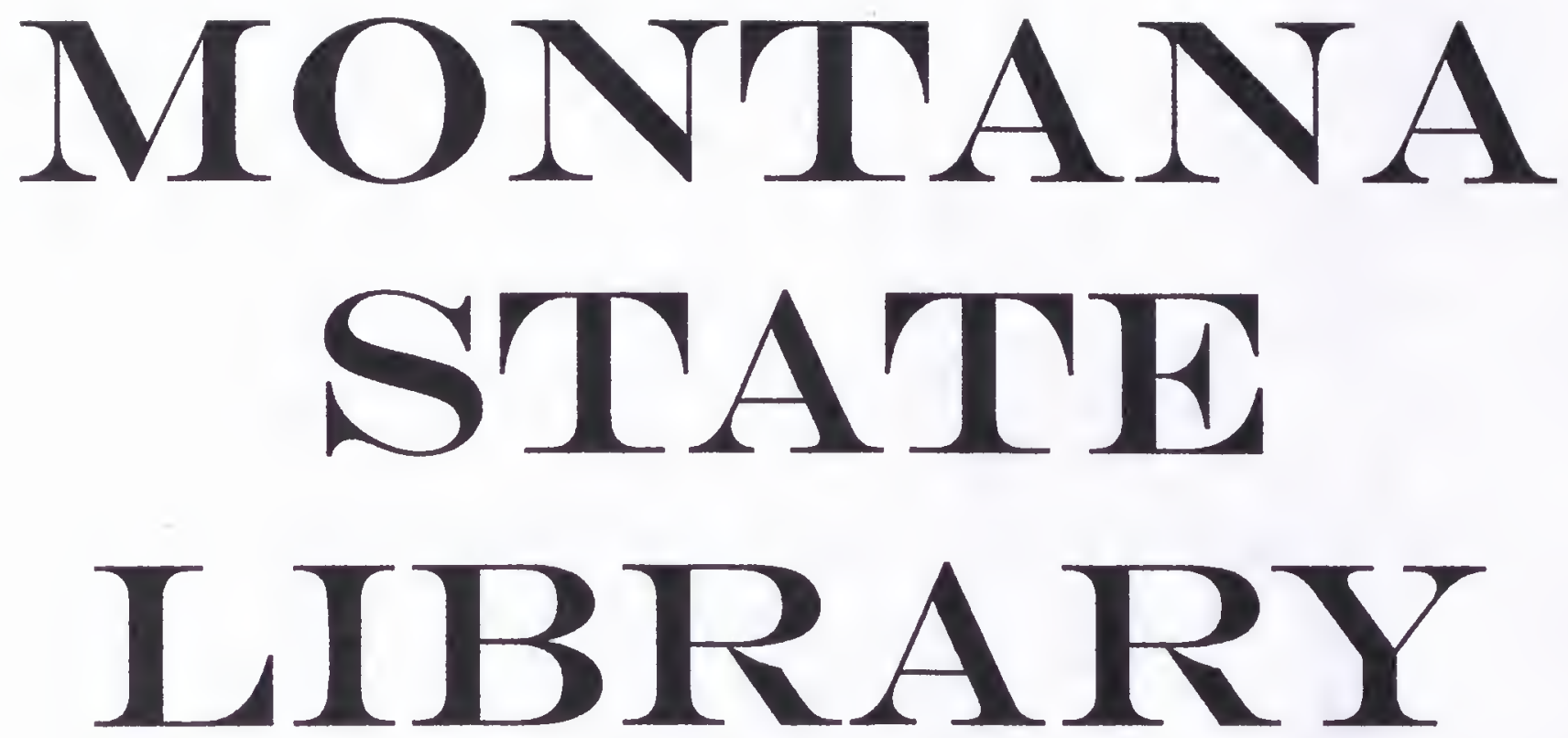

This "cover" page added by the Internet Archive for formatting purposes 